Review

\title{
Hepatocyte Growth Factor Isoforms in Tissue Repair, Cancer, and Fibrotic Remodeling
}

\author{
Ognoon Mungunsukh, Elizabeth A. McCart and Regina M. Day * \\ Department of Pharmacology, Uniformed Services University of the Health Sciences, \\ Bethesda, MD 20814-4799, USA; E-Mails: ognoon.mungunsukh@usuhs.edu (O.M.); \\ elizabeth.mccart@usuhs.edu (E.A.M.) \\ * Author to whom correspondence should be addressed; E-Mail: regina.day@usuhs.edu; \\ Tel.: +1-301-295-3236; Fax: +1-301-295-3220.
}

External Editor: Zimmer Yitzhak

Received: 19 August 2014; in revised form: 21 October 2014 / Accepted: 27 October 2014 / Published: 5 November 2014

\begin{abstract}
Hepatocyte growth factor (HGF), also known as scatter factor (SF), is a pleotropic factor required for normal organ development during embryogenesis. In the adult, basal expression of HGF maintains tissue homeostasis and is up-regulated in response to tissue injury. HGF expression is necessary for the proliferation, migration, and survival of epithelial and endothelial cells involved in tissue repair in a variety of organs, including heart, lung, kidney, liver, brain, and skin. The administration of full length HGF, either as a protein or using exogenous expression methodologies, increases tissue repair in animal models of tissue injury and increases angiogenesis. Full length HGF is comprised of an $N$-terminal hairpin turn, four kringle domains, and a serine protease-like domain. Several naturally occurring alternatively spliced isoforms of HGF were also identified. The NK1 variant contains the $N$-terminal hairpin and the first kringle domain, and the NK2 variant extends through the second kringle domain. These alternatively spliced forms of HGF activate the same receptor, MET, but they differ from the full length protein in their cellular activities and their biological functions. Here, we review the species-specific expression of the HGF isoforms, their regulation, the signal transduction pathways they activate, and their biological activities.
\end{abstract}

Keywords: hepatocyte growth factor; NK1; NK2; MET receptor; signal transduction; truncated isoforms; tissue repair 


\section{Introduction}

Hepatocyte growth factor (HGF), or scatter factor (SF), was first identified as a factor from the plasma from humans and rabbits, and also rat platelets, that could induce the proliferation of hepatocytes in culture [1-3]. Following its initial discovery, HGF was demonstrated to be produced primarily by mesenchymal cell types, especially fibroblasts, in a variety of tissues including lung, heart, kidney, liver, skin, and brain [4-14]. HGF is required for normal embryonic development, and mice lacking HGF display failure for the development of multiple organs [9,15-20]. The HGF receptor, MET, was identified as a $145 \mathrm{kDa}$ tyrosine kinase receptor with a single transmembrane domain, a juxtamembrane regulatory domain, and a $C$-terminal multifunctional docking domain that was phosphorylated in response to HGF [21,22]. Like HGF, MET is expressed in a wide variety of tissues [9,23-28]. However, in contrast with HGF, MET is localized primarily on epithelial and endothelial cell types [29-31]. Thus, in normal tissues, it is believed that HGF functions in homeostasis as a paracrine factor synthesized by mesenchymal cells to induce the survival and maintenance of the other cells of the tissue $[9,26]$.

Shortly after the discovery of HGF, several isoforms of the factor were identified. Full length HGF was shown by Northern blots to correspond to an mRNA of about $6 \mathrm{~Kb}$, encoding a protein of $\sim 82,000 \mathrm{kDa}$, that is proteolytically processed to produce a $\sim 69 \mathrm{kDa}$ alpha subunit with a single disulfide bond to a $\sim 34 \mathrm{kDa}$ beta subunit [32]. Structurally, the full length HGF protein was shown to contain an $N$-terminal hairpin loop and four kringle domains in the alpha subunit, and a serine protease-like domain in the beta subunit [32,33]. An alternatively processed mRNA for human $H G F$ was identified by Northern blot, with an estimated size of $1.5 \mathrm{~kb}$, with a predicted translation product of $\sim 33 \mathrm{kDa}$ protein containing the $N$-terminal hairpin loop and the first two kringle domains of HGF (named NK2) [34,35]. A second splice variant of human HGF was later identified by Northern blotting, a $\sim 1.2 \mathrm{~kb}$ transcript, encoding a protein of $\sim 20 \mathrm{kDa}$ protein containing the HGF $N$-terminal hairpin loop and the first kringle domain (named NK1) [36]. This later truncated isoform was also identified in murine mRNA [37]. Both the NK2 and NK1 isoforms were demonstrated to compete with HGF for binding to the same MET receptor [34,36-39]. However, the biological and cellular activities of the two truncated isoforms differ greatly from that of the full length HGF as does the regulation of their expression.

\section{Hepatocyte Growth Factor (HGF) Isoforms}

HGF is a high-molecular-weight polypeptide growth factors whose domain structure and mechanism of activation resemble those of the blood protease plasminogen, and belongs therefore to a family of plasminogen-related growth factors [33]. Besides HGF, this family includes the macrophage stimulating protein (MSP), an effector of macrophage chemotaxis and phagocytosis [40]. These two proteins share a common ancestral gene with the plasminogen and apolipoprotein. Phylogenetic studies suggest that these proteins evolved from a common ancestor that consisted of a single kringle domain and a serine protease (or serine protease-like) domain, separated by a region involved in their activation [33]. HGF and MSP have 45\% sequence homology with each other, and 40\% with plasminogen. Four main features distinguish HGF and MSP from plasminogen: (1) high-affinity 
binding to a specific membrane receptor, activating a complex cell-signaling pathway; (2) lack of enzymatic activity of the serine protease domain; (3) the number of kringle domains (four in HGF and MSP, five in plasminogen); (4) binding to heparan sulfate proteoglycans [20].

Functional orthologs of HGF and MET can be found in vertebrates from bony fishes to humans, and $H G F$ and MET related gene sequences of limited length and without clear functional similarity can be found in invertebrates as well. The most common transcript variant of $H G F$ is the full length $H G F$. The human orthologs are $4792 \mathrm{nt}$ (XM_006715956), $2820 \mathrm{nt}$ (NM_000601), and $2805 \mathrm{nt}$ (NM_001010932) long transcripts that contain 18 exons [41]. The first two transcripts encode for a 728 aa polypeptide and last one encodes a 723 aa polypeptide.

The NK1 isoform is the shortest functionally active isoform of $H G F$. In humans, it is transcribed as a 2079 nt-long transcript (NM_0010934) consisting of five exons that encode a 201 aa polypeptide. NK1 sequences are predicted in several other species including the mouse (Mus musculus, NM_00128946), rabbit (Oryctolagus cuniculus, XM_008258180), opossum (Monodelphis domestica, XM_007504021), and non-human primates (e.g., Chlorocebus sabaeus, XM_007982358). They are highly similar among different species. Primates share $\sim 98.5 \%$ sequence identity, and the murine and human $N K 1$ coding regions are $88.63 \%$ identical. The $N K 1-3$ 'UTR of primates are $\sim 95.7 \%$ identical, but the 3'UTR of rabbit and human share $71.57 \%$ identical sequence. The 3 'UTR of the murine $N K 1$ is only $48.85 \%$ identical to the human. The $H G F$ gene contains an alternative splice acceptor in the intron that follows the five coding exons among these species.

The other functionally active isoform of $H G F$ is the NK2. It is transcribed in humans as a 1292 nt (NM_001010933) or 1307 nt (NM_001010931) mRNA of seven exons, encoding 284 aa or 290 aa, respectively.

The NCBI Gnomon [42] predicted NK2 similar sequences in several other species like Chrysochloris asiatica (golden mole, XM_006834344.1), Ceratotherium simum simum (rhinoceros, XM_004431294) and Canis lipus familiaris (dog, XM_005630886), in addition to primates (Figure 1). Sequence analysis using Basic Local Alignment Search Tool (BLAST) [43] revealed that the murine $H G F$ sequence does not contain the splice sites required for the generation of NK2 (Figure 1) and data from our laboratory indicated that the $N K 2$ isoform was not expressed in mice [44]. Only primates share significant sequence similarities in the 3'UTR, e.g., Pan troglodytes (chimpanzee) XM_003318558 and Nomascus leucogenys (gibbon) XM_003252220 share 97\% similarity with the two NK2 isoforms (NM_001010933 and NM_001010931) of human (Figure 2). Although the sequences present in the NCBI Gnomon predict the expression of NK2 in dog, rhinoceros, and golden mole, supporting experimental data have not yet been produced. 
Figure 1. Generation of the $N K 2$ message. (A) A schematic comparison of hepatocyte growth factor $(H G F)$ genes. Bars and numbers indicate exons. The alternative exon used for $N K 2$ splicing is indicated by a triangle at the corresponding introns. The murine intron does not contain this alternative exon; (B) The exon (capital letters)-intron (small letters) boundary sequences for NK2 splicing. Predicted splice donor and acceptor sites are underlined. The murine sequence lacks characteristics commonly found in splice acceptor sites. The carboxy-terminal amino acids of $N K 2$ and the stop codon (*) are shown below the coding sequence.

A

Mus musculus (mouse, $65.89 \mathrm{~kb}$ )

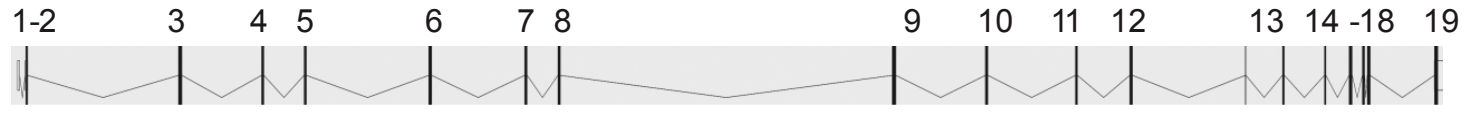

Canis lupus (dog, $80.69 \mathrm{~kb}$ )

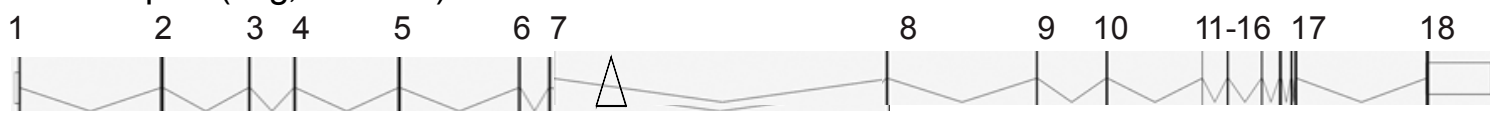

Pan troglodytes (chimpanzee, $68.40 \mathrm{~kb}$ )

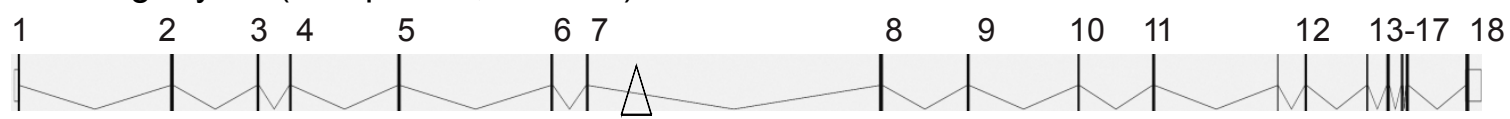

Homo sapiens (human, $67.47 \mathrm{~kb}$ )

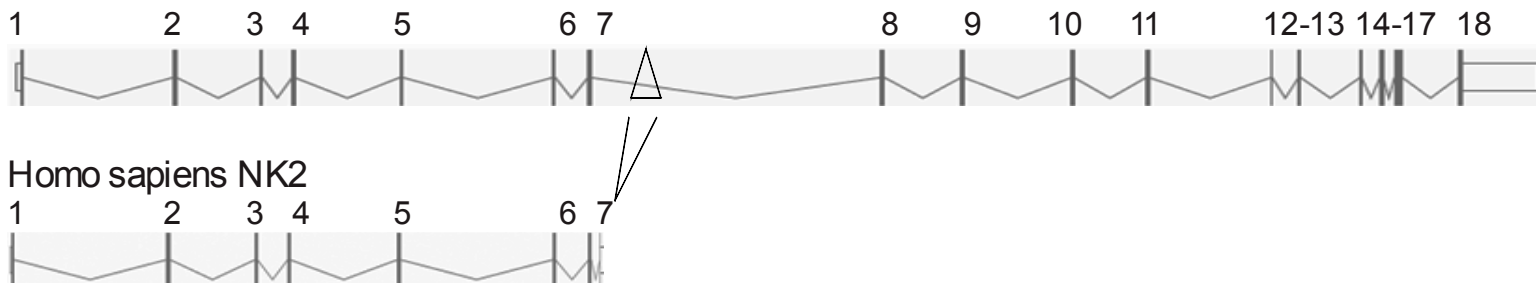

B ...GGAGTATTGTGCAATTAAAACGTG CGgtaagttag... ....attagatagagacatgctttta ... exon-intron 8-9 $\begin{array}{llllllllll}. . . E & T & C & A & I & M & C & E & \text { mouse HGF }\end{array}$ ...GGAGTACTGTGCAATTAAAATGTG TGgtaagttag... ... ttcctccccAGACATAACATGA... 3'-UTR

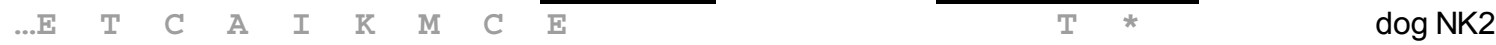
...GGAGTACTGTGCAATTAAAACATG CGgtaagtgaa... ...cctccccagAgACATAACTTGG ... 3'-UTR

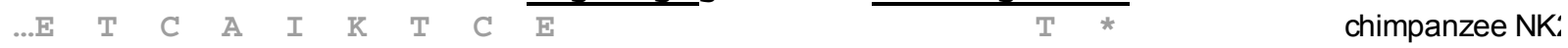

...GGAGTACTGTGCAATTAAAACATG CGgtaagtgaa... ...cctccccagAgACA TAACATGG ... 3'-UTR $\begin{array}{llllllllllll}\ldots & \mathrm{E} & \mathrm{C} & \mathrm{A} & \mathrm{I} & \mathrm{K} & \mathrm{T} & \mathrm{C} & \mathrm{E} & \mathrm{T} & * & \text { human NK2 }\end{array}$ 
Figure 2. Multiple alignment of the human NK2 3'UTR with predicted 3'UTR sequences from species using the European Molecular Biology Laboratory-European Bioinformatics Institute Clustal Omega program [45]. Asterisks indicate nucleotides identical with the human sequence; non-identical nucleotides are shown as red letters. The first two nucleotides (AG, blue) are the predicted primate splice acceptor site.

\begin{tabular}{|c|c|}
\hline Golden Mole & AGAGACATAACATGTGCTGTCAG- - ATGATGAACCTTTTCTGGTAAGTGACTGAGGTTA \\
\hline Dog & CCAGACATAACATGAGCTGTCAACTGACCATGAACCTCTTCTGGTGAATGATAGAATCAC \\
\hline Rhinocerus & CCAGACATAACATGAGCTGTCAACTGACTGTGAACCTCTTCTAGTGAATG \\
\hline ibbon & GAGACATAACATGAGCTCTCAACTGATGGTGAACCTCTTCTGGTGAGTGACAGAGGCTG \\
\hline panzee & GAGACATAACTTGGGCTCTCAACTGATGGTGAACTTCTTCTGGTGAGTGACAGAGGCTG \\
\hline & 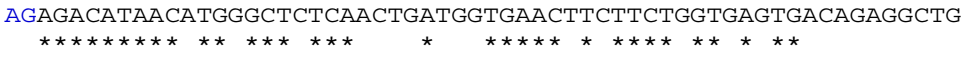 \\
\hline olden Mole & CAAAGGAGTATAATACAAGTGGATCTAATAGC - - \\
\hline og & -ACTGAAGAATAGTAAGTCTGATAGAACAATCTCCCAGACATCGTGAAGCTCTAGAGGCT \\
\hline hinocerus & СAATGAAGAATAATAAATCTAATAGATGCTTCTAATAGATGTCTTTAATCTCTAGTAGCT \\
\hline Lbbon & GAGGAAGAATAATGAGTCTAATAGAAGTTTATCACAGATGTCTCTAATCTCTATAG- - - \\
\hline himpanzee & СAATGAAGAATAATGAGTCTAATAGAAGTTTATCACAGATGTCTCTAATCTCTATAG- - - \\
\hline & $\begin{array}{c}\text { CAGTGAAGAATAATGAGTCTAATAGAAGTTTATCACAGATGTCTCTAATCTTTATAG- - } \\
* * * * * * * * * *\end{array}$ \\
\hline olden Mole & GTTAAGTGCCATTGAGTTGGTTCCAACTAATAGCAACTCTGCATAGGGTTTGCTACGATT \\
\hline Dog & GATGCCCACCTCCCTGGCTG---- - CTCGTCCACAGCCTGTATTCTGTACCAACCTGTC \\
\hline Rhinocerus & GGTCCCCCCCCCCCACCCCGGCTGTCCTTGTACGCAGCCTGCACTCTATTTCAACCTGTC \\
\hline Gibbon & - - CTGATCCCTACCTCTCTGGCTGTCTTTGTACCCAGCCTGCATTCTGTTTCGATCTGTC \\
\hline Chimpanzee & - - СТАATCCСTACСTCTCTGGCTGTCTTTGTACCCAGCCTGCATTCTGTTTCGATCCGTC \\
\hline nan & -- CTGATCCCTACCTCTCTCGCTGTCTTTGTACCCAGCCTGCATTCTGTTTCGATCTGTC \\
\hline & $\star * \quad * \quad * * \star \star * \quad *$ \\
\hline olden Mole & ACCAACTTATGGTTAACAGTCTAGTGCTTATCCTTCAGTACC \\
\hline Dog & TTAGCTGTGCT- - -G- - - TGTTTGTTTTGTATGTACTGGCCTTTGACC- - - AACA \\
\hline Rhinocerus & TTTTGGCAGTCCTATA----GTCT--TTTTCTATATATTGGCCTTTACCC---- АACT \\
\hline ibbon & TTTAGCAGTCCATAC- - - - AATCATTTTTCTACATGCTGGCССTTACCC- - - - AGCT \\
\hline anzee & TTTTAGCAGTCCATAC- - --AATCATTTTTCTACATGCTGGCCСTTTCCC- - - - AGCT \\
\hline $\operatorname{man}$ & TTTAGCAGTCCATAC- - -- AATCATTTTTCTACATGCTGGCССTTACCT- - - - AGCT \\
\hline & * * \\
\hline Golden Mole & TCCCAAGATTCTTATAAAAGCTTCTTATAG - - - - - \\
\hline og $\quad$ & СТCCTGAACTTATGATAGAAGC \\
\hline cerus & GTCTTCAATTTATAATAAAAAGTGTTTTTTCTCGCTTG \\
\hline & TTTCTGAATTTACAATAAAAАСТАТTTTTTAАССТGTT \\
\hline & TTTCTGAATTTACAATAAAAАСТАТTTTTTAACG - - - \\
\hline man & TTTCTGAATTTACAATAAAAACTATTTTTTAACGTGAA \\
\hline & $\star \quad * \quad * \star \quad \star * \star * \star * \quad *$ \\
\hline
\end{tabular}

\section{Regulation of Expression of $H G F$ and Its Isoforms}

$H G F$ is expressed in most tissues, and both mRNA and protein have been detected in the liver, lung, kidney, skin, and brain. The $H G F$ gene promoter has been extensively analyzed to determine the mechanism(s) of its regulation in development/growth, tissue repair, fibrosis, and oncogenesis [46-48]. $H G F$ expression is positively regulated by other growth factors, such as epidermal growth factor, platelet-derived growth factor, and several members of the fibroblast growth factor family [49]. $H G F$ expression is also increased in response to inflammatory cytokines interleukin (IL)- $1 \alpha$ and $-1 \beta$, IL-6, IL-8, and interferon- $\gamma$ [50-53]; the regulation by these cytokines may be linked to $H G F$ expression during early phases of inflammation that precede tissue repair. Analyses of the $H G F$ promoter revealed functional cis-elements for transcription factor binding including IL-6 response elements, activating protein-2 (AP2) elements, nuclear factor-1 (NF1) elements, nuclear factor-IL6 elements, a cyclic AMP response element, several binding sites for the SP family of transcription factors, an upstream stimulatory factor (USF) element, a chick ovalbumin upstream promoter-transcription factor element, a complex $\mathrm{C} 1$ element, and the cell type specific CCAAT/enhancer binding protein (C/EBP) binding element [54-57]. Another element in the $H G F$ promoter, the peroxisome proliferator-activated receptor gamma (PPAR $\gamma$ )-responsive element, was shown to strongly regulate $H G F$ expression in response to either PPAR $\gamma 1$ or PPAR $\gamma 2$ ligands, but because this binding site 
overlaps with the NF1 and chicken ovalbumin upstream promoter-transcription factor elements, the binding of these other factors repress PPAR $\gamma$ activation [55]. Specific regulation of $H G F$ in response to tissue injury and/or inflammation is believed to occur through factor binding to the C/EBP element [56].

$H G F$ expression is tightly regulated, and several elements within the promoter suppress its expression. Binding of activating protein-2 (AP2) to a regulatory site -230 to $-260 \mathrm{bp}$ upstream of the transcriptional start site suppresses $H G F$ expression [58]. Another repressor of $H G F$ expression, a repeat of 30 deoxyadenosines (termed "deoxyadenosine tract element" or DATE) is located about 750 bp upstream of the $H G F$ start site [59]. The DATE element is thought to be a hot spot for promoter mutations leading to $H G F$ dysregulation in breast cancer [59].

$H G F$ expression is potently suppressed in fibroblasts and other cell types by the pro-fibrotic cytokine transforming growth factor beta 1 (TGF- $\beta 1$ ), by hypoxia, and by glucocorticoids [50,60]. In a human fetal lung fibroblast cell line, TGF- $\beta 1$ down-regulated HGF protein and mRNA. Interestingly, the regulation of $H G F$ occurred without affecting $N K 2$ expression in the cells [61]. Recent findings in human adult lung fibroblasts provide evidence that the selective regulation of $H G F$ by TGF- $\beta 1$ occurs through TGF- $\beta 1$ up-regulation of miR-199a-3p [44]. The miR-199a-3p binds to the $H G F$ mRNA 3'UTR leading to degradation of $H G F$ mRNA. The NK2 mRNA has an alternative 3'UTR sequence that is not regulated by miR-199a-3p [44].

\section{Cellular Signaling by HGF and Its Truncated Isoforms}

HGF is a pleiotrophic factor, inducing motogenesis, mitogenesis, survival, and in some cell types, morphogenesis $[8,62,63]$. HGF signaling occurs through its high affinity receptor, MET, a tyrosine kinase receptor $[21,22]$. Analysis of functional residues of the MET receptor revealed that, in addition to phosphorylation of tyrosines in the kinase domain $\left(\mathrm{Y}^{1234}\right.$ and $\left.\mathrm{Y}^{1235}\right)$, two other phosphotyrosines in the carboxy-terminal multifunctional docking domain, $\mathrm{Y}^{1349}$ and $\mathrm{Y}^{1356}$, regulate downstream signaling [64-68]. Tyrosine phosphorylation of MET allows its interaction with adaptor proteins and signaling molecules, resulting in the downstream activation of major signaling pathways including Ras/p42/p44 mitogen activated protein kinase (MAPK), phosphatidylinositol 3-kinase (PI3K)/Akt, src kinase, protein kinase $\mathrm{C}$ isoforms $(\mathrm{PKC})$, signal transducer and activator of transcription 3 (STAT3), small GTP-binding proteins Rap1, Rac, and Rho, and [69-77]. A number of investigations have attempted to identify individual signaling pathways required for the various biological effects of HGF, and there appears to be substantial overlap [76-79]. While mitogenic and antiapoptotic actions of HGF appear to require p42/p44 MAPK, PI3K/Akt, and STAT3, the motogenic activity requires PI3K and src kinase [76-79]. Morphogenesis and tubulogenesis appear to require PI3K as well as other pathways downstream of the Grb2 adaptor protein [79]. HGF inhibition of apoptosis from a variety of causes including oxidative stress, DNA damaging agents, or signaling by angiotensin II has been shown to require PI3K/Akt, p42/p44 MAPK, and STAT3 [78,80-84].

Following their initial discoveries, it was demonstrated that NK1 and NK2 bound to MET and induced its phosphorylation in a competitive manner with full length HGF $[34,36,38,85]$. In early studies, it appeared that the level of total MET tyrosine phosphorylation by the truncated isoforms in cell cultures of breast epithelial cells was somewhat reduced compared to MET phosphorylation by 
full length HGF [38]. However, later studies with higher amounts of refolded, purified protein, the MET phosphorylation could be induced by the truncated isoforms to the same total levels as with full length $\operatorname{HGF}[36,85,86]$.

NK1 induced motility in Madin Darby canine kidney (MDCK) cells and 32D cells expressing MET [85,87-89]. At high concentrations, NK1 was found to induce proliferation in a breast cancer epithelial cell line and in BALB/MK cells, MCF-10A cells, and in BaF3 cells expressing MET, albeit at a lower level than HGF $[36,85,87,90-92]$. However, NK1 was not shown to induce proliferation in the A549 lung cancer cell line, possibly due to lower levels of the factor that were used [38]. High concentrations of NK1 were also reported to be capable of inducing branching morphogenesis in endothelial cells [87]. In BALB/MK cells, NK1 was demonstrated to activate p42/p44 MAPK at levels similar to full length HGF [89]. In a non-tumorigenic human prostate epithelial cell line, NK1 was demonstrated to activate p42/p44 MAPK, Akt, srk kinase, p125 focal adhesion kinase, SMAD2/3, and STAT3 [93]. Although NK1 has been demonstrated to recapitulate most of the actions of full length HGF, it is not known whether the signaling of NK1 in cells is the same as for full length HGF.

Like NK1, NK2 induced motility in MDCK cells, but NK2 failed to induce motility in human umbilical vein endothelial cells [85-87]. In contrast, NK2 did not induce proliferation in any cell line tested, and NK2 did not induced branching morphogenesis [34,85-87]. Furthermore, NK2 could competitively inhibit HGF-induced proliferation and morphogenesis [85,87]. Interestingly, examination of NK2-induced signal transduction in cell culture demonstrated that NK2 was capable of activating both PI3K and p42/p44 MAPK in 32D cells expressing MET and in a breast cancer epithelial cell line, suggesting that these two pathways were not sufficient to induce proliferation in response to MET activation [86]. In another effort to characterize NK2-induced signaling in vivo, a study of melanoma cells in NK2 transgenic mice demonstrated that the tissues of these mice had reduced MET phosphorylation and reduced p42/p44 MAPK activation in contrast with HGF transgenic mice, suggesting that signaling by this isoform in vivo is compromised [94]. The signal transduction by NK2 in normal non-transformed cells remains poorly understood.

\section{Biological Functions of HGF and Its Isoforms}

\subsection{HGF Isoforms during Development}

HGF plays an essential role during development in the placenta [95], liver [15], and kidney [17,96]. HGF is also critical for normal neuronal development and for limb skeletal muscle [16,97-99]. Consequently, knockout mice for $H G F$ die in utero during early stages of embryogenesis [99]. A pattern of HGF secretion, along with other essential growth factors, has been noted in a variety of developmental epithelial layer, including in the intestinal lamina propria, where epithelial and mesenchymal interactions are essential for normal epithelial cell differentiation [100,101].

Although the expression patterns and effects of HGF have been investigated in development, the roles of the two naturally occurring isoforms of HGF, NK1 and NK2, in development are not yet understood. One study of HGF isoform expression during development in macaques found low levels of expression of both NK1 and NK2 as well as novel forms of NK1 and NK2 (dNK1 and dNK2) with a five amino acid deletion in the first kringle domain [102]. Increased HGF and all isoforms were 
found to be increased at 144 days of gestation, and all forms were found in the endometrium and placenta [102]. The role of the expression of the HGF isoforms during embryogenesis and development is not yet known.

\subsection{Role of HGF Isoforms for Tissue Homeostasis and Repair}

HGF is a growth factor, survival factor, and mitogen for epithelial and endothelial cells from the lung, skin, kidney, liver, heart, and brain [103-111]. In the adult, basal expression of HGF is believed to be important for normal tissue homeostasis, where the local production of HGF by resident mesenchymal cells maintains the specialized epithelium of the tissue $[9,10,13,26,28,29,63,112-117]$. For instance, in the kidney, expression of HGF by mesangial cells in the tissue microenvironment is believed to maintain normal growth of kidney endothelial cells [112], and HGF is required for trans-telencephalic migration of interneurons and for neuronal survival for brain cell homeostasis [118].

HGF expression is greatly increased in response to most types of tissue injury [5]. HGF expression is induced in animals after experimental renal, cardiac, pulmonary, adrenal gland, or hepatic injury $[1,112,115,119-128]$. For the vascular endothelium, HGF is a potent proliferative factor critical for angiogenesis, a process often required for repair of tissue injury [129]. Interestingly, the lung was also shown to synthesize HGF in response to injuries in distal organs, suggesting a paracrine function for tissue repair by the lung [130]. Increased expression of HGF in response to tissue injuries was demonstrated to be related to tissue repair activities in vivo [131,132]. Additionally, the time course of HGF up-regulation or administration of HGF correlated with the increased proliferation of epithelial cells following experimentally-induced tissue injury [119,133,134]. Direct evidence for the role of HGF in tissue repair was provided in experiments in which the blockade of HGF using neutralizing antibodies resulted in the inhibition of hepatocyte proliferation for liver regeneration and kidney regeneration following injury [135,136]. Also, the generation of a conditional knockout of HGF in mice was demonstrated to result in impaired liver regeneration following $\mathrm{CCl}_{4}$ treatment [137]. Severely impaired liver generation was also observed after partial hepatectomy in a conditional MET mutant mouse with MET-null phenotype [138]. The failure in normal liver repair was characterized by altered cell cycle progression and cell cycle entry. Others have shown that conditional knockout of MET caused hypersensitivity to FAS-induced apoptosis of hepatocytes and impaired recovery from centrolobular lesions as a result of persistent inflammatory reaction, overproduction of osteopontin, early calcification, and suppressed hepatocyte migration into the injured area [139]. Wound healing experiments with mice in which MET was conditionally inactivated in the epidermis demonstrated that MET-deficient mice required twice as much time as wild type mice for the healing and only MET positive cells that escaped knockout recombination were involved in this delayed skin healing [140].

The administration of HGF, whether as a purified protein or through ectopic expression methods, was demonstrated to increase normal tissue repair in experimental injury models of the lung, skin, liver, kidney, heart, pancreas, and brain, and improves angiogenesis [24,31,131,141-157]. Of critical importance, HGF administration increases normal repair processes and inhibits fibrotic remodeling and/or scar tissue formation [24,142,145,148,150,156,158-167]. Currently, non-viral plasmids for the expression of HGF are being explored for efficacy in treatment of critical limb ischemia and for peripheral neuropathy in diabetes $[168,169]$. 
The basal expression of NK1 and NK2 has been observed in multiple tissues, including in normal fibroblasts from the lung [44]. Interestingly, the expression of NK1 and NK2, but not full length HGF, was observed in chondrocytes [170]. In general, the normal biological function of the truncated isoforms is not known. Over-expression of the HGF truncated isoforms in vivo has been shown to have varying effects on cellular proliferation, survival and migration, cellular events that are all believed to be required for normal tissue repair.

In cell culture, NK1 has been shown to act as a mitogen and anti-apoptotic factor for normal hepatocytes in culture [171]. Transgenic mice over-expressing NK1 had similarities to mice over-expressing full length HGF, including "enlarged livers, ectopic skeletal-muscle formation, progressive renal disease, aberrant pigment cell localization, precocious mammary lobuloalveolar development" [37]. However, in NK1 transgenic mice, some of these abnormalities were reduced compared with HGF transgenic mice. For instance, in NK1 mice, livers were enlarged 1.5-fold, compared with 2-3-fold increases observed in HGF mice, and incidences of cancers were lower in the NK1 mice [37]. In another study, NK1 over-expression was observed to increase hepatocyte proliferation in vivo and to reduce liver fibrosis in murine partial hepatectomy model [171]. Administration of recombinant NK1 protein was also demonstrated to induce the proliferation of isolated islets in culture and to induce proliferation pancreatic $\beta$-cells in a murine model of type 2 diabetes [172].

Murine models of tissue injury suggest that NK2 does not induce the proliferation of normal cells and may inhibit normal tissue repair. NK2 transgenic mice did not exhibit the phenotypic consequences observed in response to HGF over-expression, including the inhibition of hyperplastic lesions of the kidney or olfactory mucosa, and abnormalities of the mammary gland and skeletal muscle [94]. NK2 transgenic mice also did not display gastrointestinal obstruction, progressive renal disease, or enlarged livers [94]. Interestingly, metastasis of malignant melanoma cells were extremely activated in NK2 transgenic mice compared to the wild type. The number of metastatic cells in the liver were nearly the same as that obtained with HGF transgenic mice, and the size of metastatic tumors in the NK2 livers were equivalent to wild type [94]. Additionally, NK2 over-expression in combination with HGF over-expression in bi-transgenic mice blocked the HGF-induced alterations [94]. At the cellular level, NK2 was demonstrated to inhibit HGF-induced proliferation of normal hepatocytes in culture and in vivo [94,147]. In a murine model of liver repair after partial hepatectomy, it was found that NK2 over-expression blocked liver tissue regeneration [173].

In an early investigation of a murine model of liver injury, the inducible expression of HGF both prevented the induction of liver injury and induced tissue repair [147]. In contrast, this report demonstrated that NK2 augmented $\mathrm{CCl}_{4}$-induced liver injury, but did not inhibit endogenous hepatocyte proliferation following liver injury [147]. In this study, the final level of liver recovery was not examined [147]. In a later study of NK2 over-expression following $\mathrm{CCl}_{4}$-induced liver injury in mice, it was found that NK2 promoted liver fibrosis and prevented normal tissue repair [174].

\subsection{HGF Isoforms in Cancer}

Expression of HGF and/or its receptor MET is increased in a wide variety of cancers [175]. The HGF/MET axis is believed to contribute significantly to proliferation, metastasis, extracellular matrix remodeling, tumor cell survival, and angiogenesis associated with tumors [176-178]. 
$M E T$, originally identified as a proto-oncogene [179,180], was found to be up-regulated in a variety of cancers, inducing its constitutive expression [181-186]. Oncogenic forms of MET have been detected that induce constitutive activity and in some cases new functions [179,187,188]. HGF over-expression has also been demonstrated to be sufficient for neoplastic transformation in cells expressing normal levels of wild type MET, and HGF over-expression in transgenic mice drives the development of multiple cancers [189-194]. Because of the widespread expression of MET and HGF in cancer, their expression has been analyzed for cancer severity, and the degrees of expression of MET and HGF are believed to indicate the progression of disease as well as serve as prognostic markers for some forms of cancer [195-198].

Early studies suggested that NK1 and NK2 did not induce cancer cell proliferation in cell culture, and that the activation of motility was also reduced in some cancer cell types. For instance, both NK1 and NK2 inhibited the proliferation and motility of A549 lung cancer cell line in vitro [176]. In these same cells, both NK1 and NK2 altered the expression of matrix metaloproteinases, suggesting that the mechanism for the reduction of cellular motility in part lay in altered interactions with the extracellular matrix and increasing the adhesion capacity of the cells [176]. However, later studies suggested that NK1 at higher concentrations could induce both mitogenic and motogenic activities in a variety of cancer cells $[36,199]$; these activities were demonstrated to be improved in the presence of cell surface heparin or other mechanisms to induce NK1 dimerization [88,90,200]. In contrast, NK2 failed to induce proliferation of most cancer cells, and had varying effects on cancer cell motility [94,201].

In vivo studies challenged the original views of $\mathrm{NK} 1$ and $\mathrm{NK} 2$ as inhibitors of cancer. Transgenic mice over-expressing NK1 had a number of similar oncogenic events as found in mice over-expressing full length HGF, including mammary, hepatocellular, and melanocytic tumors [37]. In transgenic mice over-expressing NK2, NK2 inhibited HGF-induced melanoma cell proliferation in vivo [94]. NK2 gene transfer was also demonstrated to inhibit proliferation of glioma cells in vivo [201]. However, in the melanoma model system, NK2 over-expression did induce higher levels of metastasis of the cancer cells [94].

\section{Clinical Applications of HGF Isoforms}

HGF has been used successfully as both protein and DNA as a therapeutic agent in preclinical animal models for ischemic heart disease, renal fibrosis, pulmonary fibrosis, and for other diseases where there is a need for increased tissues repair [142,148,163,164,202,203]. In humans, HGF has been investigated for the clinical treatment of myocardial injury (NIH clinical trial identifier: NCT01233336). To date, these studies have revealed that HGF is an early marker of myocardial injury and prognostic factor for post myocardial infarction. Other clinical trials (NCT00189540 and NCT00060892) in critical limb ischemia revealed that $H G F$ gene therapy is safe and improved wound healing, reduced the necessity for amputation, improved pain at rest, and improved hemodynamic measurement without adverse effects on the quality of life in the critical limb ischemia population. HGF is also under investigation for treatment of diabetic peripheral neuropathy [169]. Furthermore, plasmid expression of $H G F$ is in Phase III Clinical Trials to treat severe peripheral arterial disease in Japan [204], and adenovirus mediated $H G F$ gene-transfer is under investigation as a potential treatment 
for coronary artery disease in a Phase I Clinical Trial in China [205]. Phase I/II Clinical Trials of recombinant human HGF protein are currently underway for the treatment of acute spinal cord injury (NCT02193334).

$\mathrm{NK}$, an artificial HGF isomer, contains the $N$-terminal hairpin domain and the subsequent four-kringle domains, and has been shown to act as an antagonist to HGF monogenic activity [206]. Based on the abundant preclinical data appears to be a potential role for the use of $N K 4$ in gene therapy for the treatment of cancer, including pancreatic cancer, gastric carcinoma, hepatocellular carcinoma, breast and endometrial cancer, lung cancer, and prostate cancer [207-214]. Due to its activity in the suppression of inflammatory cytokine production by $\mathrm{CD}^{+} \mathrm{T}$ cells, preclinical models have also shown that NK4 may provide a new approach for the treatment of rheumatoid arthritis [215,216]. The use of NK4 in ovarian cancer is currently under investigation.

In contrast with full length HGF and the synthetic HGF antagonist NK4, the naturally occurring isoforms of HGF are not currently in clinical trials. Although NK1 has been shown to induce all the signal transduction pathways of full length HGF, its lower level activity suggests that it may not be as beneficial as full length HGF for clinical applications. Additionally, NK2, though its ability to antagonize HGF proliferation could be useful for anti-cancer therapy, however its partial activation of MET may also preclude this application.

\section{Conclusions}

The naturally occurring isoforms of HGF, NK1 and NK2 are expressed in human tissues during development and in normal adults. Studies in cell culture and in transgenic animals suggest that NK1 is capable of recapitulating normal HGF signaling and biological activities, while NK2 appears to be an antagonist for HGF-induced cellular proliferation. NK2 expression is increased relative to full length HGF in human fibrotic organ diseases, and it is possible that NK2 may play a role in the failure of normal repair. The normal biological roles of the HGF truncated isoforms remain to be determined. Further understanding of the normal functions of these proteins may provide insight for their use in human diseases.

\section{Acknowledgments}

This work was prepared as part of their official duties. Title 17 U.S.C. $\$ 105$ provides that "Copyright protection under this title is not available for any work of the United States Government." Title 17 U.S.C $\$ 101$ defined a U.S. Government work as a work prepared by a military service member or employees of the U.S. Government as part of that person's official duties. The views in this article are those of the authors and do not necessarily reflect the views, official policy, or position of the Uniformed Services University of the Health Sciences, the Armed Forces Radiobiology Research Institute, Department of the Navy, Department of Defense or the U.S. Federal Government.

\section{Author Contributions}

Ognoon Mungunsukh, Elizabeth A. McCart, and Regina M. Day contributed to the writing and revision of this review article. 


\section{Conflicts of Interest}

The authors declare no conflict of interest.

\section{References}

1. Gohda, E.; Tsubouchi, H.; Nakayama, H.; Hirono, S.; Sakiyama, O.; Takahashi, K.; Miyazaki, H.; Hashimoto, S.; Daikuhara, Y. Purification and partial characterization of hepatocyte growth factor from plasma of a patient with fulminant hepatic failure. J. Clin. Investig. 1988, 81, 414-419.

2. Zarnegar, R.; Michalopoulos, G. Purification and biological characterization of human hepatopoietin A, a polypeptide growth factor for hepatocytes. Cancer Res. 1989, 49, 3314-3320.

3. Nakamura, T.; Nawa, K.; Ichihara, A.; Kaise, N.; Nishino, T. Purification and subunit structure of hepatocyte growth factor from rat platelets. FEBS Lett. 1987, 224, 311-316.

4. Rubin, J.S.; Chan, A.M.; Bottaro, D.P.; Burgess, W.H.; Taylor, W.G.; Cech, A.C.; Hirschfield, D.W.; Wong, J.; Miki, T.; Finch, P.W.; et al. A broad-spectrum human lung fibroblast-derived mitogen is a variant of hepatocyte growth factor. Proc. Natl. Acad. Sci. USA 1991, 88, 415-419.

5. Nakamura, T.; Mizuno, S. The discovery of hepatocyte growth factor (HGF) and its significance for cell biology, life sciences and clinical medicine. Proc. Jpn. Acad. B 2010, 86, 588-610.

6. Benkhoucha, M.; Santiago-Raber, M.L.; Schneiter, G.; Chofflon, M.; Funakoshi, H.; Nakamura, T.; Lalive, P.H. Hepatocyte growth factor inhibits CNS autoimmunity by inducing tolerogenic dendritic cells and $\mathrm{CD}_{25} 5^{+} \mathrm{FOXP}^{+}$regulatory T cells. Proc. Natl. Acad. Sci. USA 2010, 107, 6424-6429.

7. Hickey, D.G.; Frenkel, S.R.; di Cesare, P.E. Clinical applications of growth factors for articular cartilage repair. Am. J. Orthop. 2003, 32, 70-76.

8. Stoker, M. Effect of scatter factor on motility of epithelial cells and fibroblasts. J. Cell. Physiol. 1989, 139, 565-569.

9. Matsumoto, K.; Nakamura, T. Hepatocyte growth factor (HGF) as a tissue organizer for organogenesis and regeneration. Biochem. Biophys. Res. Commun. 1997, 239, 639-644.

10. Goke, M.; Kanai, M.; Podolsky, D.K. Intestinal fibroblasts regulate intestinal epithelial cell proliferation via hepatocyte growth factor. Am. J. Physiol. 1998, 274, G809-G818.

11. Tabata, M.J.; Kim, K.; Liu, J.G.; Yamashita, K.; Matsumura, T.; Kato, J.; Iwamoto, M.; Wakisaka, S.; Matsumoto, K.; Nakamura, T.; et al. Hepatocyte growth factor is involved in the morphogenesis of tooth germ in murine molars. Development 1996, 122, 1243-1251.

12. Hamanoue, M.; Takemoto, N.; Matsumoto, K.; Nakamura, T.; Nakajima, K.; Kohsaka, S. Neurotrophic effect of hepatocyte growth factor on central nervous system neurons in vitro. J. Neurosci. Res. 1996, 43, 554-564.

13. Matsumoto, K.; Date, K.; Ohmichi, H.; Nakamura, T. Hepatocyte growth factor in lung morphogenesis and tumor invasion: Role as a mediator in epithelium-mesenchyme and tumor-stroma interactions. Cancer Chemother. Pharmacol. 1996, 38, S42-S47.

14. Montesano, R.; Matsumoto, K.; Nakamura, T.; Orci, L. Identification of a fibroblast-derived epithelial morphogen as hepatocyte growth factor. Cell 1991, 67, 901-908. 
15. Schmidt, C.; Bladt, F.; Goedecke, S.; Brinkmann, V.; Zschiesche, W.; Sharpe, M.; Gherardi, E.; Birchmeier, C. Scatter factor/hepatocyte growth factor is essential for liver development. Nature 1995, 373, 699-702.

16. Takayama, H.; la Rochelle, W.J.; Anver, M.; Bockman, D.E.; Merlino, G. Scatter factor/hepatocyte growth factor as a regulator of skeletal muscle and neural crest development. Proc. Natl. Acad. Sci. USA 1996, 93, 5866-5871.

17. Santos, O.F.; Barros, E.J.; Yang, X.M.; Matsumoto, K.; Nakamura, T.; Park, M.; Nigam, S.K. Involvement of hepatocyte growth factor in kidney development. Dev. Biol. 1994, 163, 525-529.

18. Sonnenberg, E.; Meyer, D.; Weidner, K.M.; Birchmeier, C. Scatter factor/hepatocyte growth factor and its receptor, the c-Met tyrosine kinase, can mediate a signal exchange between mesenchyme and epithelia during mouse development. J. Cell Biol. 1993, 123, 223-235.

19. Maina, F.; Casagranda, F.; Audero, E.; Simeone, A.; Comoglio, P.M.; Klein, R.; Ponzetto, C. Uncoupling of GRB2 from the Met receptor in vivo reveals complex roles in muscle development. Cell 1996, 87, 531-542.

20. Birchmeier, C.; Gherardi, E. Developmental roles of HGF/SF and its receptor, the c-Met tyrosine kinase. Trends Cell Biol. 1998, 8, 404-410.

21. Bottaro, D.P.; Rubin, J.S.; Faletto, D.L.; Chan, A.M.; Kmiecik, T.E.; vande Woude, G.F.; Aaronson, S.A. Identification of the hepatocyte growth factor receptor as the c-Met proto-oncogene product. Science 1991, 251, 802-804.

22. Park, M.; Dean, M.; Kaul, K.; Braun, M.J.; Gonda, M.A.; vande Woude, G. Sequence of Met protooncogene cDNA has features characteristic of the tyrosine kinase family of growth-factor receptors. Proc. Natl. Acad. Sci. USA 1987, 84, 6379-6383.

23. Zachow, R.; Uzumcu, M. The hepatocyte growth factor system as a regulator of female and male gonadal function. J. Endocrinol. 2007, 195, 359-371.

24. Mizuno, S.; Matsumoto, K.; Nakamura, T. HGF as a renotrophic and anti-fibrotic regulator in chronic renal disease. Front. Biosci. 2008, 13, 7072-7086.

25. Madonna, R.; Rokosh, G.; de Caterina, R.; Bolli, R. Hepatocyte growth factor/Met gene transfer in cardiac stem cells - Potential for cardiac repair. Basic Res. Cardiol. 2010, 105, 443-452.

26. Warburton, D.; Wuenschell, C.; Flores-Delgado, G.; Anderson, K. Commitment and differentiation of lung cell lineages. Biochem. Cell Biol. 1998, 76, 971-995.

27. Kasai, S.; Sugimura, K.; Matsumoto, K.; Nishi, N.; Kishimoto, T.; Nakamura, T. Hepatocyte growth factor is a paracrine regulator of rat prostate epithelial growth. Biochem. Biophys. Res. Commun. 1996, 228, 646-652.

28. Matsumoto, K.; Tajima, H.; Nakamura, T. Hepatocyte growth factor is a potent stimulator of human melanocyte DNA synthesis and growth. Biochem. Biophys. Res. Commun. 1991, 176, 45-51.

29. Yang, X.M.; Park, M. Expression of the hepatocyte growth factor/scatter factor receptor tyrosine kinase is localized to epithelia in the adult mouse. Lab. Investig. 1995, 73, 483-491.

30. Nakamura, Y.; Morishita, R.; Higaki, J.; Kida, I.; Aoki, M.; Moriguchi, A.; Yamada, K.; Hayashi, S.; Yo, Y.; Nakano, H.; et al. Hepatocyte growth factor is a novel member of the endothelium-specific growth factors: Additive stimulatory effect of hepatocyte growth factor with basic fibroblast growth factor but not with vascular endothelial growth factor. J. Hypertens. 1996, 14, 1067-1072. 
31. Hayashi, S.; Morishita, R.; Higaki, J.; Aoki, M.; Moriguchi, A.; Kida, I.; Yoshiki, S.; Matsumoto, K.; Nakamura, T.; Kaneda, Y.; et al. Autocrine-paracrine effects of over-expression of hepatocyte growth factor gene on growth of endothelial cells. Biochem. Biophys. Res. Commun. 1996, 220, 539-545.

32. Nakamura, T.; Nishizawa, T.; Hagiya, M.; Seki, T.; Shimonishi, M.; Sugimura, A.; Tashiro, K.; Shimizu, S. Molecular cloning and expression of human hepatocyte growth factor. Nature 1989, 342, 440-443.

33. Donate, L.E.; Gherardi, E.; Srinivasan, N.; Sowdhamini, R.; Aparicio, S.; Blundell, T.L. Molecular evolution and domain structure of plasminogen-related growth factors (HGF/SF and HGF1/MSP). Protein Sci. 1994, 3, 2378-2394.

34. Chan, A.M.; Rubin, J.S.; Bottaro, D.P.; Hirschfield, D.W.; Chedid, M.; Aaronson, S.A. Identification of a competitive HGF antagonist encoded by an alternative transcript. Science 1991, 254, 1382-1385.

35. Miyazawa, K.; Kitamura, A.; Naka, D.; Kitamura, N. An alternatively processed mRNA generated from human hepatocyte growth factor gene. Eur. J. Biochem. 1991, 197, 15-22.

36. Cioce, V.; Csaky, K.G.; Chan, A.M.; Bottaro, D.P.; Taylor, W.G.; Jensen, R.; Aaronson, S.A.; Rubin, J.S. Hepatocyte growth factor (HGF)/NK1 is a naturally occurring HGF/scatter factor variant with partial agonist/antagonist activity. J. Biol. Chem. 1996, 271, 13110-13115.

37. Jakubczak, J.L.; LaRochelle, W.J.; Merlino, G. NK1, a natural splice variant of hepatocyte growth factor/scatter factor, is a partial agonist in vivo. Mol. Cell. Biol. 1998, 18, 1275-1283.

38. Lokker, N.A.; Godowski, P.J. Generation and characterization of a competitive antagonist of human hepatocyte growth factor, HGF/NK1. J. Biol. Chem. 1993, 268, 17145-17150.

39. Lokker, N.A.; Mark, M.R.; Luis, E.A.; Bennett, G.L.; Robbins, K.A.; Baker, J.B.; Godowski, P.J. Structure-function analysis of hepatocyte growth factor: Identification of variants that lack mitogenic activity yet retain high affinity receptor binding. EMBO J. 1992, 11, 2503-2510.

40. Skeel, A.; Yoshimura, T.; Showalter, S.D.; Tanaka, S.; Appella, E.; Leonard, E.J. Macrophage stimulating protein: Purification, partial amino acid sequence, and cellular activity. J. Exp. Med. 1991, 173, 1227-1234.

41. National Center for Biotechnology Information Genbank. Available online: http://www.Ncbi. Nlm.Nih.Gov/Genbank/ (accessed on 31 October 2014).

42. National Center for Biotechnology Information Gnomon, Eukaryotic Gene Prediction Tool. Available online: http://www.Ncbi.Nlm.Nih.Gov/Genome/Guide/Gnomon.Shtml (accessed on 31 October 2014).

43. Basic Local Alignment Search Tool (Blast). Available online: http://Blast.Ncbi.Nlm.Nih.Gov/ Blast.Cgi (accessed on 31 October 2014).

44. Mungunsukh, O; Day, R.M. Transforming growth factor-beta1 selectively inhibits hepatocyte growth factor expression via a micro-RNA-199-dependent posttranscriptional mechanism. Mol. Biol. Cell 2013, 24, 2088-2097.

45. European Molecular Biology Laboratory_European Bioinformatics Institute Clustal Omega Program for Multiple Sequence Alignment. Available online: http://www.Ebi.Ac.Uk/Tools/ Msa/Clustalo/ (accessed on 31 October 2014). 
46. Miyazawa, K.; Kitamura, A.; Kitamura, N. Structural organization and the transcription initiation site of the human hepatocyte growth factor gene. Biochemistry 1991, 30, 9170-9176.

47. Okajima, A.; Miyazawa, K.; Kitamura, N. Characterization of the promoter region of the rat hepatocyte-growth-factor/scatter-factor gene. Eur. J. Biochem. 1993, 213, 113-119.

48. Bell, A.W.; Jiang, J.G.; Chen, Q.; Liu, Y.; Zarnegar, R. The upstream regulatory regions of the hepatocyte growth factor gene promoter are essential for its expression in transgenic mice. J. Biol. Chem. 1998, 273, 6900-6908.

49. Gohda, E.; Matsunaga, T.; Kataoka, H.; Takebe, T.; Yamamoto, I. Induction of hepatocyte growth factor in human skin fibroblasts by epidermal growth factor, platelet-derived growth factor and fibroblast growth factor. Cytokine 1994, 6, 633-640.

50. Matsumoto, K.; Tajima, H.; Okazaki, H.; Nakamura, T. Negative regulation of hepatocyte growth factor gene expression in human lung fibroblasts and leukemic cells by transforming growth factor-beta 1 and glucocorticoids. J. Biol. Chem. 1992, 267, 24917-24920.

51. Matsumoto, K.; Okazaki, H.; Nakamura, T. Up-regulation of hepatocyte growth factor gene expression by interleukin-1 in human skin fibroblasts. Biochem. Biophys. Res. Commun. 1992, 188, 235-243.

52. Matsumoto, K.; Tajima, H.; Hamanoue, M.; Kohno, S.; Kinoshita, T.; Nakamura, T. Identification and characterization of "injurin", an inducer of expression of the gene for hepatocyte growth factor. Proc. Natl. Acad. Sci. USA 1992, 89, 3800-3804.

53. Yamamoto, H.; Teramoto, H.; Uetani, K.; Igawa, K.; Shimizu, E. Stretch induces a growth factor in alveolar cells via protein kinase. Respir. Physiol. 2001, 127, 105-111.

54. Liu, Y.; Michalopoulos, G.K.; Zarnegar, R. Structural and functional characterization of the mouse hepatocyte growth factor gene promoter. J. Biol. Chem. 1994, 269, 4152-4160.

55. Jiang, J.G.; Johnson, C.; Zarnegar, R. Peroxisome proliferator-activated receptor gamma-mediated transcriptional up-regulation of the hepatocyte growth factor gene promoter via a novel composite cis-acting element. J. Biol. Chem. 2001, 276, 25049-25056.

56. Jiang, J.G.; Zarnegar, R. A novel transcriptional regulatory region within the core promoter of the hepatocyte growth factor gene is responsible for its inducibility by cytokines via the C/EBP family of transcription factors. Mol. Cell. Biol. 1997, 17, 5758-5770.

57. Jiang, J.G.; Chen, Q.; Bell, A.; Zarnegar, R. Transcriptional regulation of the hepatocyte growth factor $(H G F)$ gene by the SP family of transcription factors. Oncogene 1997, 14, 3039-3049.

58. Jiang, J.G.; deFrances, M.C.; Machen, J.; Johnson, C.; Zarnegar, R. The repressive function of AP2 transcription factor on the hepatocyte growth factor gene promoter. Biochem. Biophys. Res. Commun. 2000, 272, 882-886.

59. Ma, J.; deFrances, M.C.; Zou, C.; Johnson, C.; Ferrell, R.; Zarnegar, R. Somatic mutation and functional polymorphism of a novel regulatory element in the $H G F$ gene promoter causes its aberrant expression in human breast cancer. J. Clin. Investig. 2009, 119, 478-491.

60. Flann, K.L.; Rathbone, C.R.; Cole, L.C.; Liu, X.; Allen, R.E.; Rhoads, R.P. Hypoxia simultaneously alters satellite cell-mediated angiogenesis and hepatocyte growth factor expression. J. Cell. Physiol. 2014, 229, 572-579.

61. Harrison, P.; Bradley, L.; Bomford, A. Mechanism of regulation of $H G F / S F$ gene expression in fibroblasts by TGF-beta1. Biochem. Biophys. Res. Commun. 2000, 271, 203-211. 
62. Rubin, J.S.; Bottaro, D.P.; Aaronson, S.A. Hepatocyte growth factor/scatter factor and its receptor, the c-Met proto-oncogene product. Biochim. Biophys. Acta 1993, 1155, 357-371.

63. Brinkmann, V.; Foroutan, H.; Sachs, M.; Weidner, K.M.; Birchmeier, W. Hepatocyte growth factor/scatter factor induces a variety of tissue-specific morphogenic programs in epithelial cells. J. Cell Biol. 1995, 131, 1573-1586.

64. Giordano, S.; Bardelli, A.; Zhen, Z.; Menard, S.; Ponzetto, C.; Comoglio, P.M. A point mutation in the Met oncogene abrogates metastasis without affecting transformation. Proc. Natl. Acad. Sci. USA 1997, 94, 13868-13872.

65. Zhu, H.; Naujokas, M.A.; Fixman, E.D.; Torossian, K.; Park, M. Tyrosine 1356 in the carboxyl-terminal tail of the $\mathrm{HGF} / \mathrm{SF}$ receptor is essential for the transduction of signals for cell motility and morphogenesis. J. Biol. Chem. 1994, 269, 29943-29948.

66. Ponzetto, C.; Bardelli, A.; Zhen, Z.; Maina, F.; dalla Zonca, P.; Giordano, S.; Graziani, A.; Panayotou, G.; Comoglio, P.M. A multifunctional docking site mediates signaling and transformation by the hepatocyte growth factor/scatter factor receptor family. Cell 1994, 77, 261-271.

67. Weidner, K.M.; Sachs, M.; Riethmacher, D.; Birchmeier, W. Mutation of juxtamembrane tyrosine residue 1001 suppresses loss-of-function mutations of the Met receptor in epithelial cells. Proc. Natl. Acad. Sci. USA 1995, 92, 2597-2601.

68. Furge, K.A.; Zhang, Y.W.; vande Woude, G.F. Met receptor tyrosine kinase: Enhanced signaling through adapter proteins. Oncogene 2000, 19, 5582-5589.

69. Graziani, A.; Gramaglia, D.; Cantley, L.C.; Comoglio, P.M. The tyrosine-phosphorylated hepatocyte growth factor/scatter factor receptor associates with phosphatidylinositol 3-kinase. J. Biol. Chem. 1991, 266, 22087-22090.

70. Sakkab, D.; Lewitzky, M.; Posern, G.; Schaeper, U.; Sachs, M.; Birchmeier, W.; Feller, S.M. Signaling of hepatocyte growth factor/scatter factor (HGF) to the small GTPase Rap1 via the large docking Protein Gab1 and the adapter protein CRKL. J. Biol. Chem. 2000, 275, 10772-10778.

71. Riordan, S.M.; Lidder, S.; Williams, R.; Skouteris, G.G. The beta-subunit of the hepatocyte growth factor/scatter factor (HGF/SF) receptor phosphorylates and associates with CrkII: Expression of CrkII enhances HGF/SF-induced mitogenesis. Biochem. J. 2000, 350, 925-932.

72. Dong, G.; Chen, Z.; Li, Z.Y.; Yeh, N.T.; Bancroft, C.C.; van Waes, C. Hepatocyte growth factor/scatter factor-induced activation of MEK and PI3K signal pathways contributes to expression of proangiogenic cytokines interleukin-8 and vascular endothelial growth factor in head and neck squamous cell carcinoma. Cancer Res. 2001, 61, 5911-5918.

73. Kodama, A.; Matozaki, T.; Fukuhara, A.; Kikyo, M.; Ichihashi, M.; Takai, Y. Involvement of an SHP-2-Rho small G protein pathway in hepatocyte growth factor/scatter factor-induced cell Scattering. Mol. Biol. Cell 2000, 11, 2565-2575.

74. Hartmann, G.; Weidner, K.M.; Schwarz, H.; Birchmeier, W. The motility signal of scatter factor/hepatocyte growth factor mediated through the receptor tyrosine kinase Met requires intracellular action of Ras. J. Biol. Chem. 1994, 269, 21936-21939.

75. Royal, I.; Lamarche-Vane, N.; Lamorte, L.; Kaibuchi, K.; Park, M. Activation of cdc42, rac, $\mathrm{PAK}$, and rho-kinase in response to hepatocyte growth factor differentially regulates epithelial cell colony spreading and dissociation. Mol. Biol. Cell 2000, 11, 1709-1725. 
76. Rahimi, N.; Tremblay, E.; Elliott, B. Phosphatidylinositol 3-kinase activity is required for hepatocyte growth factor-induced mitogenic signals in epithelial cells. J. Biol. Chem. 1996, 271, 24850-24855.

77. Rahimi, N.; Hung, W.; Tremblay, E.; Saulnier, R.; Elliott, B. c-Src kinase activity is required for hepatocyte growth factor-induced motility and anchorage-independent growth of mammary carcinoma cells. J. Biol. Chem. 1998, 273, 33714-33721.

78. Nakagami, H.; Morishita, R.; Yamamoto, K.; Taniyama, Y.; Aoki, M.; Kim, S.; Matsumoto, K.; Nakamura, T.; Higaki, J.; Ogihara, T. Anti-apoptotic action of hepatocyte growth factor through mitogen-activated protein kinase on human aortic endothelial cells. J. Hypertens. 2000, $18,1411-1420$.

79. Royal, I.; Fournier, T.M.; Park, M. Differential requirement of Grb2 and PI3-Kinase in HGF/SF-induced cell motility and tubulogenesis. J. Cell. Physiol. 1997, 173, 196-201.

80. Fan, S.; Ma, Y.X.; Wang, J.A.; Yuan, R.Q.; Meng, Q.; Cao, Y.; Laterra, J.J.; Goldberg, I.D.; Rosen, E.M. The cytokine hepatocyte growth factor/scatter factor inhibits apoptosis and enhances DNA repair by a common mechanism involving signaling through phosphatidyl inositol 3' kinase. Oncogene 2000, 19, 2212-2223.

81. Wang, X.; Zhou, Y.; Kim, H.P.; Song, R.; Zarnegar, R.; Ryter, S.W.; Choi, A.M. Hepatocyte growth factor protects against hypoxia/reoxygenation-induced apoptosis in endothelial cells. J. Biol. Chem. 2004, 279, 5237-5243.

82. Mildner, M.; Eckhart, L.; Lengauer, B.; Tschachler, E. Hepatocyte growth factor/scatter factor inhibits UVb-induced apoptosis of human keratinocytes but not of keratinocyte-derived cell lines via the phosphatidylinositol 3-kinase/Akt pathway. J. Biol. Chem. 2002, 277, 14146-14152.

83. Suzuki, A.; Hayashida, M.; Kawano, H.; Sugimoto, K.; Nakano, T.; Shiraki, K. Hepatocyte growth factor promotes cell survival from Fas-mediated cell death in hepatocellular carcinoma cells via Akt activation and Fas-death-inducing signaling complex suppression. Hepatology 2000, 32, 796-802.

84. Lee, Y.H.; Marquez, A.P.; Mungunsukh, O.; Day, R.M. Hepatocyte growth factor inhibits apoptosis by the profibrotic factor angiotensin II via extracellular signal-regulated kinase $1 / 2$ in endothelial cells and tissue explants. Mol. Biol. Cell 2010, 21, 4240-4250.

85. Stahl, S.J.; Wingfield, P.T.; Kaufman, J.D.; Pannell, L.K.; Cioce, V.; Sakata, H.; Taylor, W.G.; Rubin, J.S.; Bottaro, D.P. Functional and biophysical characterization of recombinant human hepatocyte growth factor isoforms produced in Escherichia coli. Biochem. J. 1997, 326, 763-772.

86. Day, R.M.; Cioce, V.; Breckenridge, D.; Castagnino, P.; Bottaro, D.P. Differential signaling by Alternative HGF isoforms through c-Met: Activation of both MAP kinase and PI 3-kinase pathways is insufficient for mitogenesis. Oncogene 1999, 18, 3399-3406.

87. Montesano, R.; Soriano, J.V.; Malinda, K.M.; Ponce, M.L.; Bafico, A.; Kleinman, H.K.; Bottaro, D.P.; Aaronson, S.A. Differential effects of hepatocyte growth factor isoforms on epithelial and endothelial tubulogenesis. Cell Growth Differ. 1998, 9, 355-365.

88. Jones, D.S., 2nd; Tsai, P.C.; Cochran, J.R. Engineering hepatocyte growth factor fragments with high stability and activity as Met receptor agonists and antagonists. Proc. Natl. Acad. Sci. USA 2011, 108, 13035-13040. 
89. Rubin, J.S.; Day, R.M.; Breckenridge, D.; Atabey, N.; Taylor, W.G.; Stahl, S.J.; Wingfield, P.T.; Kaufman, J.D.; Schwall, R.; Bottaro, D.P. Dissociation of heparan sulfate and receptor binding eomains of hepatocyte growth factor reveals that heparan sulfate-c-Met interaction facilitates signaling. J. Biol. Chem. 2001, 276, 32977-32983.

90. Schwall, R.H.; Chang, L.Y.; Godowski, P.J.; Kahn, D.W.; Hillan, K.J.; Bauer, K.D.; Zioncheck, T.F. Heparin induces dimerization and confers proliferative activity onto the hepatocyte growth factor antagonists NK1 and NK2. J. Cell Biol. 1996, 133, 709-718.

91. Sakata, H.; Stahl, S.J.; Taylor, W.G.; Rosenberg, J.M.; Sakaguchi, K.; Wingfield, P.T.; Rubin, J.S. Heparin binding and oligomerization of hepatocyte growth factor/scatter factor isoforms. Heparan sulfate glycosaminoglycan requirement for Met binding and signaling. J. Biol. Chem. 1997, 272, 9457-9463.

92. Tolbert, W.D.; Daugherty-Holtrop, J.; Gherardi, E.; vande Woude, G.; Xu, H.E. Structural basis for agonism and antagonism of hepatocyte growth factor. Proc. Natl. Acad. Sci. USA 2010, 107, 13264-13269.

93. Pavone, L.M.; Cattaneo, F.; Rea, S.; de Pasquale, V.; Spina, A.; Sauchelli, E.; Mastellone, V.; Ammendola, R. Intracellular signaling cascades triggered by the NK1 fragment of hepatocyte growth factor in human prostate epithelial cell line PNT1A. Cell. Signal. 2011, 23, 1961-1971.

94. Otsuka, T.; Jakubczak, J.; Vieira, W.; Bottaro, D.P.; Breckenridge, D.; Larochelle, W.J.; Merlino, G. Disassociation of Met-mediated biological responses in vivo: The natural hepatocyte growth factor/scatter factor splice variant NK2 antagonizes growth but facilitates metastasis. Mol. Cell. Biol. 2000, 20, 2055-2065.

95. Wolf, H.K.; Zarnegar, R.; Oliver, L.; Michalopoulos, G.K. Hepatocyte growth factor in human placenta and trophoblastic disease. Am. J. Pathol. 1991, 138, 1035-1043.

96. Woolf, A.S.; Kolatsi-Joannou, M.; Hardman, P.; Andermarcher, E.; Moorby, C.; Fine, L.G.; Jat, P.S.; Noble, M.D.; Gherardi, E. Roles of hepatocyte growth factor/scatter factor and the Met receptor in the early development of the metanephros. J. Cell Biol. 1995, 128, 171-184.

97. Maina, F.; Hilton, M.C.; Ponzetto, C.; Davies, A.M.; Klein, R. Met receptor signaling is required for sensory nerve development and HGF promotes axonal growth and survival of sensory neurons. Genes Dev. 1997, 11, 3341-3350.

98. Takebayashi, T.; Iwamoto, M.; Jikko, A.; Matsumura, T.; Enomoto-Iwamoto, M.; Myoukai, F.; Koyama, E.; Yamaai, T.; Matsumoto, K.; Nakamura, T.; et al. Hepatocyte growth factor/scatter factor modulates cell motility, proliferation, and proteoglycan synthesis of chondrocytes. J. Cell Biol. 1995, 129, 1411-1419.

99. Bladt, F.; Riethmacher, D.; Isenmann, S.; Aguzzi, A.; Birchmeier, C. Essential role for the c-Met receptor in the migration of myogenic precursor cells into the limb bud. Nature 1995, 376, 768-771.

100. Chuva de Sousa Lopes, S.M.; Mummery, C.I. Differentiation in early development. In Essentials of Stem Cell Biology, 2nd ed.; Lanza, R., Ed.; Academic Press: San Diego, CA, USA, 2009; pp. 119-130.

101. Defrances, M.C.; Wolf, H.K.; Michalopoulos, G.K.; Zarnegar, R. The presence of hepatocyte growth factor in the developing rat. Development 1992, 116, 387-395. 
102. Lindsey, J.S.; Brenner, R.M. Novel hepatocyte growth factor/scatter factor isoform transcripts in the macaque endometrium and placenta. Mol. Hum. Reprod. 2002, 8, 81-87.

103. Kitta, K.; Day, R.M.; Ikeda, T.; Suzuki, Y.J. Hepatocyte growth factor protects cardiac myocytes against oxidative stress-induced apoptosis. Free Radic. Biol. Med. 2001, 31, 902-910.

104. Okada, M.; Sugita, K.; Inukai, T.; Goi, K.; Kagami, K.; Kawasaki, K.; Nakazawa, S. Hepatocyte growth factor protects small airway epithelial cells from apoptosis induced by tumor necrosis factor-alpha or oxidative stress. Pediatr. Res. 2004, 56, 336-344.

105. Liu, Y. Hepatocyte growth factor promotes renal epithelial cell survival by dual mechanisms. Am. J. Physiol. 1999, 277, F624-F633.

106. Bussolino, F.; di Renzo, M.F.; Ziche, M.; Bocchietto, E.; Olivero, M.; Naldini, L.; Gaudino, G.; Tamagnone, L.; Coffer, A.; Comoglio, P.M. Hepatocyte growth factor is a potent angiogenic factor which stimulates endothelial cell motility and growth. J. Cell Biol. 1992, 119, 629-641.

107. Van Adelsberg, J.; Sehgal, S.; Kukes, A.; Brady, C.; Barasch, J.; Yang, J.; Huan, Y. Activation of hepatocyte growth factor (HGF) by endogenous HGF activator is required for metanephric kidney morphogenesis in vitro. J. Biol. Chem. 2001, 276, 15099-15106.

108. Stolz, D.B.; Michalopoulos, G.K. Comparative effects of hepatocyte growth factor and epidermal growth factor on motility, morphology, mitogenesis, and signal transduction of primary rat hepatocytes. J. Cell. Biochem. 1994, 55, 445-464.

109. Singh-Kaw, P.; Zarnegar, R.; Siegfried, J.M. Stimulatory effects of hepatocyte growth factor on normal and neoplastic human bronchial epithelial cells. Am. J. Physiol. 1995, 268, L1012-L1020.

110. Mason, R.J.; McCormick-Shannon, K.; Rubin, J.S.; Nakamura, T.; Leslie, C.C. Hepatocyte growth factor is a mitogen for alveolar type II cells in rat lavage fluid. Am. J. Physiol. 1996, 271, L46-L53.

111. Liu, Y.; Sun, A.M.; Dworkin, L.D. Hepatocyte growth factor protects renal epithelial cells from apoptotic cell death. Biochem. Biophys. Res. Commun. 1998, 246, 821-826.

112. Yo, Y.; Morishita, R.; Yamamoto, K.; Tomita, N.; Kida, I.; Hayashi, S.; Moriguchi, A.; Kato, S.; Matsumoto, K.; Nakamura, T.; et al. Actions of hepatocyte growth factor as a local modulator in the kidney: Potential role in pathogenesis of renal disease. Kidney Int. 1998, 53, 50-58.

113. Sheehan, S.M.; Allen, R.E. Skeletal muscle satellite cell proliferation in response to members of the fibroblast growth factor family and hepatocyte growth factor. J. Cell. Physiol. 1999, 181, 499-506.

114. Li, D.Q.; Tseng, S.C. Differential regulation of keratinocyte growth factor and hepatocyte growth factor/scatter factor by different cytokines in human corneal and limbal fibroblasts. J. Cell. Physiol. 1997, 172, 361-372.

115. Crosby, L.M.; Waters, C.M. Epithelial repair mechanisms in the lung. Am. J. Physiol. Lung Cell. Mol. Physiol. 2010, 298, L715-L731.

116. Skibinski, G.; Elborn, J.S.; Ennis, M. Bronchial epithelial cell growth regulation in fibroblast cocultures: The role of hepatocyte growth factor. Am. J. Physiol. Lung Cell. Mol. Physiol. 2007, 293, L69-L76.

117. Trusolino, L.; Bertotti, A.; Comoglio, P.M. Met dignalling: Principles and functions in development, organ regeneration and cancer. Nat. Rev. Mol. Cell Biol. 2010, 11, 834-848.

118. Powell, E.M.; Mars, W.M.; Levitt, P. Hepatocyte growth factor/scatter factor is a motogen for interneurons migrating from the ventral to dorsal telencephalon. Neuron 2001, 30, 79-89. 
119. Zarnegar, R.; deFrances, M.C.; Kost, D.P.; Lindroos, P.; Michalopoulos, G.K. Expression of hepatocyte growth factor mRNA in regenerating rat liver after partial hepatectomy. Biochem. Biophys. Res. Commun. 1991, 177, 559-565.

120. Igawa, T.; Matsumoto, K.; Kanda, S.; Saito, Y.; Nakamura, T. Hepatocyte growth factor may function as a renotropic factor for regeneration in rats with acute renal injury. Am. J. Physiol. 1993, 265, F61-F69.

121. Ueda, H.; Nakamura, T.; Matsumoto, K.; Sawa, Y.; Matsuda, H. A potential cardioprotective role of hepatocyte growth factor in myocardial infarction in rats. Cardiovasc. Res. 2001, 51, 41-50.

122. Adamson, I.Y.; Bakowska, J. KGF and HGF are growth factors for mesothelial cells in pleural lavage fluid after intratracheal asbestos. Exp. Lung Res. 2001, 27, 605-616.

123. Yanagita, K.; Matsumoto, K.; Sekiguchi, K.; Ishibashi, H.; Niho, Y.; Nakamura, T. Hepatocyte growth factor may act as a pulmotrophic factor on lung regeneration after acute lung injury. J. Biol. Chem. 1993, 268, 21212-21217.

124. Douglas, D.; Chen, G.; Khalil, N. Increase in the beta chain of hepatocyte growth factor (HGF beta) precedes c-Met expression after bleomycin-induced lung injury in the rat. Exp. Lung Res. 2002, 28, 301-314.

125. Yamazaki, H.; Matsumoto, K.; Inoue, T.; Nose, T.; Murayama, S.; Teshima, T.; Ozeki, S.; Koizumi, M.; Nakamura, T. Induction of hepatocyte growth factor in the liver, kidney and lung following total body irradiation in rat. Cytokine 1996, 8, 927-932.

126. Liu, Y.; Tolbert, E.M.; Lin, L.; Thursby, M.A.; Sun, A.M.; Nakamura, T.; Dworkin, L.D. Up-regulation of hepatocyte growth factor receptor: An amplification and targeting mechanism for hepatocyte growth factor action in acute renal failure. Kidney Int. 1999, 55, 442-453.

127. Verghese, G.M.; McCormick-Shannon, K.; Mason, R.J.; Matthay, M.A. Hepatocyte growth factor and keratinocyte growth factor in the pulmonary edema fluid of patients with acute lung injury. Biologic and clinical significance. Am. J. Respir. Crit. Care Med. 1998, 158, 386-394.

128. Sato, T.; Yoshinouchi, T.; Sakamoto, T.; Fujieda, H.; Murao, S.; Sato, H.; Kobayashi, H.; Ohe, T. Hepatocyte growth factor (HGF): A new biochemical marker for acute myocardial infarction. Heart Vessels 1997, 12, 241-246.

129. Yasuda, S.; Goto, Y.; Sumida, H.; Noguchi, T.; Baba, T.; Miyazaki, S.; Nonogi, H. Angiotensin-converting enzyme inhibition restores hepatocyte growth factor production in patients with congestive heart failure. Hypertension 1999, 33, 1374-1378.

130. Yanagita, K.; Nagaike, M.; Ishibashi, H.; Niho, Y.; Matsumoto, K.; Nakamura, T. Lung may have an endocrine function producing hepatocyte growth factor in response to injury of distal organs. Biochem. Biophys. Res. Commun. 1992, 182, 802-809.

131. Kawaida, K.; Matsumoto, K.; Shimazu, H.; Nakamura, T. Hepatocyte growth factor prevents scute renal failure and accelerates renal regeneration in mice. Proc. Natl. Acad. Sci. USA 1994, 91, 4357-4361.

132. Adamson, I.Y.; Bakowska, J. Relationship of keratinocyte growth factor and hepatocyte growth factor levels in rat lung lavage fluid to epithelial cell regeneration after bleomycin. Am. J. Pathol. 1999, 155, 949-954.

133. Ohmichi, H.; Matsumoto, K.; Nakamura, T. In vivo mitogenic action of HGF on lung epithelial cells: Pulmotrophic role in lung regeneration. Am. J. Physiol. 1996, 270, L1031-L1039. 
134. Panos, R.J.; Patel, R.; Bak, P.M. Intratracheal administration of hepatocyte growth factor/scatter factor stimulates rat alveolar type II cell proliferation in vivo. Am. J. Respir. Cell Mol. Biol. 1996, 15, 574-581.

135. Burr, A.W.; Toole, K.; Chapman, C.; Hines, J.E.; Burt, A.D. Anti-hepatocyte growth factor antibody inhibits hepatocyte proliferation during liver regeneration. J. Pathol. 1998, 185, 298-302.

136. Liu, Y.; Rajur, K.; Tolbert, E.; Dworkin, L.D. Endogenous hepatocyte growth factor ameliorates chronic renal injury by activating matrix degradation pathways. Kidney Int. 2000, 58, 2028-2043.

137. Phaneuf, D.; Moscioni, A.D.; leClair, C.; Raper, S.E.; Wilson, J.M. Generation of a mouse expressing a conditional knockout of the hepatocyte growth factor hene: Demonstration of impaired liver regeneration. DNA Cell Biol. 2004, 23, 592-603.

138. Borowiak, M.; Garratt, A.N.; Wustefeld, T.; Strehle, M.; Trautwein, C.; Birchmeier, C. Met provides essential signals for liver regeneration. Proc. Natl. Acad. Sci. USA 2004, 101, 10608-10613.

139. Huh, C.G.; Factor, V.M.; Sanchez, A.; Uchida, K.; Conner, E.A.; Thorgeirsson, S.S. Hepatocyte growth factor/c-Met signaling pathway is required for efficient liver regeneration and repair. Proc. Natl. Acad. Sci. USA 2004, 101, 4477-4482.

140. Chmielowiec, J.; Borowiak, M.; Morkel, M.; Stradal, T.; Munz, B.; Werner, S.; Wehland, J.; Birchmeier, C.; Birchmeier, W. c-Met is essential for wound healing in the skin. J. Cell Biol. 2007, 177, 151-162.

141. Liu, X.L.; Sato, S.; Dai, W.; Yamanaka, N. The protective effect of hepatocyte growth-promoting factor (PHGF) against hydrogen peroxide-induced acute lung injury in rats. Med. Electron Microsc. 2001, 34, 92-102.

142. Mizuno, S.; Matsumoto, K.; Li, M.Y.; Nakamura, T. HGF reduces advancing lung fibrosis in mice: A potential role for MMP-dependent myofibroblast apoptosis. FASEB J. 2005, 19, $580-582$.

143. Okano, J.; Shiota, G.; Kawasaki, H. Protective action of hepatocyte growth factor for acute liver injury caused by D-galactosamine in transgenic mice. Hepatology 1997, 26, 1241-1249.

144. Yang, J.; Dai, C.; Liu, Y. Hepatocyte growth factor gene therapy and angiotensin II blockade synergistically attenuate renal interstitial fibrosis in mice. J. Am. Soc. Nephrol. 2002, 13, 2464-2477.

145. Watanabe, M.; Ebina, M.; Orson, F.M.; Nakamura, A.; Kubota, K.; Koinuma, D.; Akiyama, K.; Maemondo, M.; Okouchi, S.; Tahara, M.; et al. Hepatocyte growth factor gene transfer to alveolar septa for effective suppression of lung fibrosis. Mol. Ther. 2005, 12, 58-67.

146. Yang, J.; Chen, S.; Huang, L.; Michalopoulos, G.K.; Liu, Y. Sustained expression of naked plasmid DNA encoding hepatocyte growth factor in mice promotes liver and overall body growth. Hepatology 2001, 33, 848-859.

147. Otsuka, T.; Takagi, H.; Horiguchi, N.; Toyoda, M.; Sato, K.; Takayama, H.; Mori, M. CCL4-induced acute liver injury in mice is inhibited by hepatocyte growth factor over-expression but stimulated by NK2 over-expression. FEBS Lett. 2002, 532, 391-395.

148. Umeda, Y.; Marui, T.; Matsuno, Y.; Shirahashi, K.; Iwata, H.; Takagi, H.; Matsumoto, K.; Nakamura, T.; Kosugi, A.; Mori, Y.; et al. Skeletal muscle targeting in vivo electroporation-mediated $H G F$ gene therapy of bleomycin-induced pulmonary fibrosis in mice. Lab. Investig. 2004, 84, $836-844$. 
149. Toyoda, M.; Takayama, H.; Horiguchi, N.; Otsuka, T.; Fukusato, T.; Merlino, G.; Takagi, H.; Mori, M. Overexpression of hepatocyte growth factor/scatter factor promotes vascularization and granulation tissue formation in vivo. FEBS Lett. 2001, 509, 95-100.

150. Xue, F.; Takahara, T.; Yata, Y.; Kuwabara, Y.; Shinno, E.; Nonome, K.; Minemura, M.; Takahara, S.; Li, X.; Yamato, E.; et al. Hepatocyte growth factor gene therapy accelerates regeneration in cirrhotic mouse livers after hepatectomy. Gut 2003, 52, 694-700.

151. Bevan, D.; Gherardi, E.; Fan, T.P.; Edwards, D.; Warn, R. Diverse and potent activities of HGF/SF in skin wound repair. J. Pathol. 2004, 203, 831-838.

152. Nakanishi, K.; Uenoyama, M.; Tomita, N.; Morishita, R.; Kaneda, Y.; Ogihara, T.; Matsumoto, K.; Nakamura, T.; Maruta, A.; Matsuyama, S.; et al. Gene transfer of human hepatocyte growth factor into rat skin wounds mediated by liposomes coated with the Sendai virus (Hemagglutinating Virus of Japan). Am. J. Pathol. 2002, 161, 1761-1772.

153. Ono, I.; Yamashita, T.; Hida, T.; Jin, H.Y.; Ito, Y.; Hamada, H.; Akasaka, Y.; Ishii, T.; Jimbow, K. Local administration of hepatocyte growth factor gene enhances the regeneration of dermis in acute incisional wounds. J. Surg. Res. 2004, 120, 47-55.

154. Warzecha, Z.; Dembinski, A.; Ceranowicz, P.; Konturek, S.; Tomaszewska, R.; Stachura, J.; Nakamura, T.; Konturek, P.C. Inhibition of cyclooxygenase-2 reduces the protective effect of hepatocyte growth factor in experimental pancreatitis. Eur. J. Pharmacol. 2004, 486, 107-119.

155. Dai, C.; Yang, J.; Liu, Y. Single injection of naked plasmid encoding hepatocyte growth factor prevents cell death and ameliorates acute renal failure in mice. J. Am. Soc. Nephrol. 2002, 13, 411-422.

156. Kitamura, K.; Fujiyoshi, K.; Yamane, J.; Toyota, F.; Hikishima, K.; Nomura, T.; Funakoshi, H.; Nakamura, T.; Aoki, M.; Toyama, Y.; et al. Human hepatocyte growth factor promotes functional recovery in primates after spinal cord injury. PLoS One 2011, 6, e27706.

157. Nakamura, T.; Sakai, K.; Matsumoto, K. Hepatocyte growth factor twenty years on: Much more than a growth factor. J. Gastroenterol. Hepatol. 2011, 26, 188-202.

158. Yaekashiwa, M.; Nakayama, S.; Ohnuma, K.; Sakai, T.; Abe, T.; Satoh, K.; Matsumoto, K.; Nakamura, T.; Takahashi, T.; Nukiwa, T. Simultaneous or delayed Administration of hepatocyte growth factor equally represses the fibrotic changes in murine lung injury induced by bleomycin. A morphologic study. Am. J. Respir. Crit. Care Med. 1997, 156, 1937-1944.

159. Yang, J.; Liu, Y. Blockage of tubular epithelial to myofibroblast transition by hepatocyte growth factor prevents renal interstitial fibrosis. J. Am. Soc. Nephrol. 2002, 13, 96-107.

160. Dohi, M.; Hasegawa, T.; Yamamoto, K.; Marshall, B.C. Hepatocyte growth factor attenuates collagen accumulation in a murine model of pulmonary fibrosis. Am. J. Respir. Crit. Care Med. 2000, 162, 2302-2307.

161. Sato, M.; Kakubari, M.; Kawamura, M.; Sugimoto, J.; Matsumoto, K.; Ishii, T. The decrease in total collagen fibers in the liver by hepatocyte growth factor after formation of cirrhosis induced by thioacetamide. Biochem. Pharmacol. 2000, 59, 681-690.

162. Tahara, M.; Matsumoto, K.; Nukiwa, T.; Nakamura, T. Hepatocyte growth factor leads to recovery from alcohol-induced fatty liver in rats. J. Clin. Investig. 1999, 103, 313-320.

163. Yang, J.; Dai, C.; Liu, Y. Systemic administration of naked plasmid encoding hepatocyte growth factor ameliorates chronic renal fibrosis in mice. Gene Ther. 2001, 8, 1470-1479. 
164. Gazdhar, A.; Fachinger, P.; van Leer, C.; Pierog, J.; Gugger, M.; Friis, R.; Schmid, R.A.; Geiser, T. Gene transfer of hepatocyte growth factor by electroporation reduces bleomycin-induced lung fibrosis. Am. J. Physiol. Lung Cell. Mol. Physiol. 2007, 292, L529-L536.

165. Iwasaki, T.; Imado, T.; Kitano, S.; Sano, H. Hepatocyte growth factor ameliorates dermal sclerosis in the tight-skin mouse model of scleroderma. Arthrit. Res. Ther. 2006, 8, R161.

166. Zhou, D.; Tan, R.J.; Lin, L.; Zhou, L.; Liu, Y. Activation of hepatocyte growth factor receptor, c-Met, in renal tubules is required for renoprotection after acute kidney injury. Kidney Int. 2013, $84,509-520$.

167. Liu, X.; Shen, W.; Yang, Y.; Liu, G. Therapeutic implications of mesenchymal stem cells transfected with hepatocyte growth factor transplanted in rat kidney with unilateral ureteral obstruction. J. Pediatr. Surg. 2011, 46, 537-545.

168. Henry, T.D.; Hirsch, A.T.; Goldman, J.; Wang, Y.L.; Lips, D.L.; McMillan, W.D.; Duval, S.; Biggs, T.A.; Keo, H.H. Safety of a non-viral plasmid-encoding dual isoforms of hepatocyte growth factor in critical limb ischemia patients: A Phase I study. Gene Ther. 2011, 18, 788-794.

169. Ajroud-Driss, S.; Christiansen, M.; Allen, J.A.; Kessler, J.A. Phase 1/2 open-label dose-escalation study of plasmid DNA expressing two isoforms of hepatocyte growth factor in patients with painful diabetic peripheral neuropathy. Mol. Ther. 2013, 21, 1279-1286.

170. Guevremont, M.; Martel-Pelletier, J.; Massicotte, F.; Tardif, G.; Pelletier, J.P.; Ranger, P.; Lajeunesse, D.; Reboul, P. Human adult chondrocytes express hepatocyte growth factor (HGF) isoforms but not HGF: Potential implication of osteoblasts on the presence of HGF in cartilage. J. Bone Miner. Res. 2003, 18, 1073-1081.

171. Ross, J.; Gherardi, E.; Mallorqui-Fernandez, N.; Bocci, M.; Sobkowicz, A.; Rees, M.; Rowe, A.; Ellmerich, S.; Massie, I.; Soeda, J.; et al. Protein rngineered variants of hepatocyte growth factor/scatter factor promote proliferation of primary human hepatocytes and in rodent liver. Gastroenterology 2012, 142, 897-906.

172. Gaddy, D.F.; Riedel, M.J.; Pejawar-Gaddy, S.; Kieffer, T.J.; Robbins, P.D. In vivo expression of HGF/NK1 and GLP-1 from dsAAV vectors enhances pancreatic $\beta$-cell proliferation and improves pathology in the $\mathrm{db} / \mathrm{db}$ mouse model of fiabetes. Diabetes 2010, 59, 3108-3116.

173. Otsuka, T.; Horiguchi, N.; Kanda, D.; Kosone, T.; Yamazaki, Y.; Yuasa, K.; Sohara, N.; Kakizaki, S.; Sato, K.; Takagi, H.; et al. Overexpression of NK2 inhibits liver regeneration after partial hepatectomy in mice. World J. Gastroenterol. 2005, 11, 7444-7449.

174. Hagiwara, S.; Otsuka, T.; Yamazaki, Y.; Kosone, T.; Sohara, N.; Ichikawa, T.; Sato, K.; Kakizaki, S.; Takagi, H.; Mori, M. Overexpression of NK2 promotes liver fibrosis in carbon tetrachloride-induced chronic liver injury. Liver Int. 2008, 28, 126-131.

175. Christensen, J.G.; Burrows, J.; Salgia, R. c-Met as a target for human cancer and characterization of inhibitors for therapeutic intervention. Cancer Lett. 2005, 225, 1-26.

176. Ramanujum, R.; Lin, Y.L.; Liu, J.K.; He, S. Regulatory expression of MMP-8/MMP-9 and inhibition of proliferation, migration and invasion in human lung cancer A549 cells in the presence of HGF variants. Kaohsiung J. Med. Sci. 2013, 29, 530-539.

177. Yashiro, M.; Chung, Y.S.; Inoue, T.; Nishimura, S.; Matsuoka, T.; Fujihara, T.; Sowa, M. Hepatocyte growth factor (HGF) produced by peritoneal fibroblasts may affect mesothelial cell morphology and promote peritoneal dissemination. Int. J. Cancer 1996, 67, 289-293. 
178. Yamazaki, H.; Takeuchi, E.; Tang, J.T.; Fukushima, S.; Inoue, T.; Shinkawa, K.; Watanabe, Y.; Tanaka, E.; Teshima, T.; Ozeki, S.; et al. Effect of thoracic irradiation on hepatocyte growth factor in rat lung and in bronchoalveolar lavage fluid of patients with thoracic malignancies. Eur. Respir. J. 1997, 10, 2539-2544.

179. Park, M.; Dean, M.; Cooper, C.S.; Schmidt, M.; O’Brien, S.J.; Blair, D.G.; vande Woude, G.F. Mechanism of Met oncogene activation. Cell 1986, 45, 895-904.

180. Cooper, C.S.; Park, M.; Blair, D.G.; Tainsky, M.A.; Huebner, K.; Croce, C.M.; vande Woude, G.F. Molecular cloning of a new transforming gene from a chemically transformed human cell line. Nature 1984, 311, 29-33.

181. Faletto, D.L.; Tsarfaty, I.; Kmiecik, T.E.; Gonzatti, M.; Suzuki, T.; vande Woude, G.F. Evidence for non-covalent clusters of the c-Met proto-oncogene product. Oncogene 1992, 7, 1149-1157.

182. Bardelli, A.; Pugliese, L.; Comoglio, P.M. "Invasive-growth" signaling by the Met/HGF receptor: The hereditary renal carcinoma connection. Biochim. Biophys. Acta 1997, 1333, M41-M51.

183. Schmidt, L.; Duh, F.M.; Chen, F.; Kishida, T.; Glenn, G.; Choyke, P.; Scherer, S.W.; Zhuang, Z.; Lubensky, I.; Dean, M.; et al. Germline and somatic mutations in the tyrosine kinase domain of the Met proto-oncogene in papillary renal carcinomas. Nat. Genet. 1997, 16, 68-73.

184. Cooper, C.S.; Tempest, P.R.; Beckman, M.P.; Heldin, C.H.; Brookes, P. Amplification and over-expression of the Met gene in spontaneously transformed NIH3T3 mouse fibroblasts. EMBO J. 1986, 5, 2623-2628.

185. Ponzetto, C.; Giordano, S.; Peverali, F.; Della Valle, G.; Abate, M.L.; Vaula, G.; Comoglio, P.M. c-Met is amplified but not mutated in a cell line with an activated Met tyrosine kinase. Oncogene 1991, 6, 553-559.

186. Rahimi, N.; Tremblay, E.; McAdam, L.; Park, M.; Schwall, R.; Elliott, B. Identification of a hepatocyte growth factor autocrine loop in a murine mammary carcinoma. Cell Growth Differ. 1996, 7, 263-270.

187. Jeffers, M.; Schmidt, L.; Nakaigawa, N.; Webb, C.P.; Weirich, G.; Kishida, T.; Zbar, B.; vande Woude, G.F. Activating mutations for the Met tyrosine kinase receptor in human cancer. Proc. Natl. Acad. Sci. USA 1997, 94, 11445-11450.

188. Lee, J.H.; Gao, C.F.; Lee, C.C.; Kim, M.D.; vande Woude, G.F. An alternatively spliced form of Met receptor is tumorigenic. Exp. Mol. Med. 2006, 38, 565-573.

189. Rong, S.; Bodescot, M.; Blair, D.; Dunn, J.; Nakamura, T.; Mizuno, K.; Park, M.; Chan, A.; Aaronson, S.; vande Woude, G.F. Tumorigenicity of the Met proto-oncogene and the gene for hepatocyte growth factor. Mol. Cell. Biol. 1992, 12, 5152-5158.

190. Takayama, H.; LaRochelle, W.J.; Sabnis, S.G.; Otsuka, T.; Merlino, G. Renal tubular hyperplasia, polycystic disease, and glomerulosclerosis in transgenic mice over-expressing hepatocyte growth factor/scatter factor. Lab. Investig. 1997, 77, 131-138.

191. Takayama, H.; LaRochelle, W.J.; Sharp, R.; Otsuka, T.; Kriebel, P.; Anver, M.; Aaronson, S.A.; Merlino, G. Diverse tumorigenesis associated with aberrant development in mice over-expressing hepatocyte growth factor/scatter factor. Proc. Natl. Acad. Sci. USA 1997, 94, 701-706.

192. Hjertner, O.; Torgersen, M.L.; Seidel, C.; Hjorth-Hansen, H.; Waage, A.; Borset, M.; Sundan, A. Hepatocyte growth factor (HGF) induces interleukin-11 secretion from osteoblasts: A possible role for HGF in myeloma-associated osteolytic bone disease. Blood 1999, 94, 3883-3888. 
193. Sakata, H.; Takayama, H.; Sharp, R.; Rubin, J.S.; Merlino, G.; LaRochelle, W.J. Hepatocyte growth factor/scatter factor over-expression induces growth, abnormal development, and tumor formation in transgenic mouse livers. Cell Growth Differ. 1996, 7, 1513-1523.

194. Horiguchi, N.; Takayama, H.; Toyoda, M.; Otsuka, T.; Fukusato, T.; Merlino, G.; Takagi, H.; Mori, M. Hepatocyte growth factor promotes hepatocarcinogenesis through c-Met autocrine activation and enhanced angiogenesis in transgenic mice treated with diethylnitrosamine. Oncogene 2002, 21, 1791-1799.

195. Teofili, L.; di Febo, A.L.; Pierconti, F.; Maggiano, N.; Bendandi, M.; Rutella, S.; Cingolani, A.; di Renzo, N.; Musto, P.; Pileri, S.; et al. Expression of the c-Met proto-oncogene and its ligand, hepatocyte growth factor, in hodgkin disease. Blood 2001, 97, 1063-1069.

196. Eagles, G.; Warn, A.; Ball, R.Y.; Baillie-Johnson, H.; Arakaki, N.; Daikuhara, Y.; Warn, R.M. Hepatocyte growth factor/scatter factor is present in most pleural effusion fluids from cancer patients. Br. J. Cancer 1996, 73, 377-381.

197. Sezer, O.; Jakob, C.; Eucker, J.; Niemoller, K.; Gatz, F.; Wernecke, K.; Possinger, K. Serum levels of the angiogenic cytokines basic fibroblast growth factor (bFGF), vascular endothelial growth factor (VEGF) and hepatocyte growth factor (HGF) in multiple myeloma. Eur. J. Haematol. 2001, 66, 83-88.

198. Takanami, I.; Tanana, F.; Hashizume, T.; Kikuchi, K.; Yamamoto, Y.; Yamamoto, T.; Kodaira, S. Hepatocyte growth Factor and c-Met/hepatocyte growth factor receptor in pulmonary adenocarcinomas: An evaluation of their expression as prognostic markers. Oncology 1996, 53, 392-397.

199. Yin, Y.L.; Chen, H.L.; Kuo, H.M.; He, S.P. NK3 and NK4 of HGF enhance filamin production via STAT pathway, but not NK1 and NK2 in human breast cancer cells. Acta Pharmacol. Sin. 2008, 29, 728-735.

200. Youles, M.; Holmes, O.; Petoukhov, M.V.; Nessen, M.A.; Stivala, S.; Svergun, D.I.; Gherardi, E. Engineering the NK1 fragment of hepatocyte growth factor/scatter factor as a Met receptor antagonist. J. Mol. Biol. 2008, 377, 616-622.

201. Guerin, C.; Luddy, C.; Abounader, R.; Lal, B.; Laterra, J. Glioma inhibition by HGF/NK2, an antagonist of scatter factor/hepatocyte growth factor. Biochem. Biophys. Res. Commun. 2000, 273, 287-293.

202. Jin, H.; Wyss, J.M.; Yang, R.; Schwall, R. The therapeutic potential of hepatocyte growth factor for myocardial infarction and heart failure. Curr. Pharm. Des. 2004, 10, 2525-2533.

203. Kagawa, T.; Takemura, G.; Kosai, K.; Murata, I.; Ohno, T.; Takahashi, T.; Esaki, M.; Maruyama, R.; Fujiwara, T.; Ohashi, H.; et al. Hepatocyte growth factor gene therapy slows down the progression of diabetic nephropathy in Db/Db mice. Nephron Physiol. 2006, 102, 92-102.

204. Makino, H.; Aoki, M.; Hashiya, N.; Yamasaki, K.; Azuma, J.; Sawa, Y.; Kaneda, Y.; Ogihara, T.; Morishita, R. Long-term follow-up evaluation of results from clinical trial using hepatocyte growth factor gene to treat severe peripheral arterial disease. Arterioscler. Thromb. Vasc. Biol. 2012, 32, 2503-2509.

205. Yang, Z.J.; Zhang, Y.R.; Chen, B.; Zhang, S.L.; Jia, E.Z.; Wang, L.S.; Zhu, T.B.; Li, C.J.; Wang, H.; Huang, J.; et al. Phase I clinical trial on intracoronary administration of Ad-hHGF treating severe coronary artery disease. Mol. Biol. Rep. 2009, 36, 1323-1329. 
206. Date, K.; Matsumoto, K.; Shimura, H.; Tanaka, M.; Nakamura, T. Hgf/Nk4 is a specific antagonist for pleiotrophic actions of hepatocyte growth factor. FEBS Lett. 1997, 420, 1-6.

207. Choi, D.S.; Kim, H.J.; Yoon, J.H.; Yoo, S.C.; Jo, H.; Lee, S.Y.; Min, C.K.; Ryu, H.S. Endometrial cancer invasion depends on cancer-derived tumor necrosis factor-alpha and stromal derived hepatocyte growth factor. Int. J. Cancer 2009, 124, 2528-2538.

208. Sun, Y.P.; Zhang, B.L.; Duan, J.W.; Wu, H.H.; Wang, B.Q.; Yu, Z.P.; Yang, W.J.; Shan, Y.F.; Zhou, M.T.; Zhang, Q.Y. Effect of NK4 transduction in bone marrow-derived mesenchymal stem cells on biological characteristics of pancreatic cancer cells. Int. J. Mol. Sci. 2014, 15, 3729-3745.

209. Date, K.; Matsumoto, K.; Kuba, K.; Shimura, H.; Tanaka, M.; Nakamura, T. Inhibition of tumor growth and invasion by a four-kringle antagonist (HGF/NK4) for hepatocyte growth factor. Oncogene 1998, 17, 3045-3054.

210. Tomioka, D.; Maehara, N.; Kuba, K.; Mizumoto, K.; Tanaka, M.; Matsumoto, K.; Nakamura, T. Inhibition of growth, invasion, and metastasis of human pancreatic carcinoma cells by NK4 in an orthotopic mouse model. Cancer Res. 2001, 61, 7518-7524.

211. Hirao, S.; Yamada, Y.; Koyama, F.; Fujimoto, H.; Takahama, Y.; Ueno, M.; Kamada, K.; Mizuno, T.; Maemondo, M.; Nukiwa, T.; et al. Tumor suppression effect using NK4, a molecule acting as an antagonist of HGF, on human gastric carcinomas. Cancer Gene Ther. 2002, 9, 700-707.

212. Heideman, D.A.; Overmeer, R.M.; van Beusechem, V.W.; Lamers, W.H.; Hakvoort, T.B.; Snijders, P.J.; Craanen, M.E.; Offerhaus, G.J.; Meijer, C.J.; Gerritsen, W.R. Inhibition of angiogenesis and HGF-cMet-elicited malignant processes in human hepatocellular carcinoma cells using adenoviral vector-mediated NK4 gene therapy. Cancer Gene Ther. 2005, 12, 954-962.

213. Wright, T.G.; Singh, V.K.; Li, J.J.; Foley, J.H.; Miller, F.; Jia, Z.; Elliott, B.E. Increased production and secretion of HGF alpha-chain and an antagonistic HGF fragment in a human breast cancer progression model. Int. J. Cancer 2009, 125, 1004-1015.

214. Mizuno, S.; Nakamura, T. HGF-Met cascade, a key target for inhibiting cancer metastasis: The impact of NK4 discovery on cancer biology and therapeutics. Int. J. Mol. Sci. 2013, 14, 888-919.

215. Rabquer, B.J.; Koch, A.E. NK4 therapy: A new approach to target angiogenesis and inflammation in rheumatoid arthritis. Arthrit. Res. Ther. 2013, 15, 119.

216. Tsunemi, S.; Iwasaki, T.; Kitano, S.; Matsumoto, K.; Takagi-Kimura, M.; Kubo, S.; Tamaoki, T.; Sano, H. Molecular targeting of hepatocyte growth factor by an Antagonist, NK4, in the treatment of rheumatoid arthritis. Arthrit. Res. Ther. 2013, 15, R75.

(C) 2014 by the authors; licensee MDPI, Basel, Switzerland. This article is an open access article distributed under the terms and conditions of the Creative Commons Attribution license (http://creativecommons.org/licenses/by/4.0/). 